\title{
Working
}

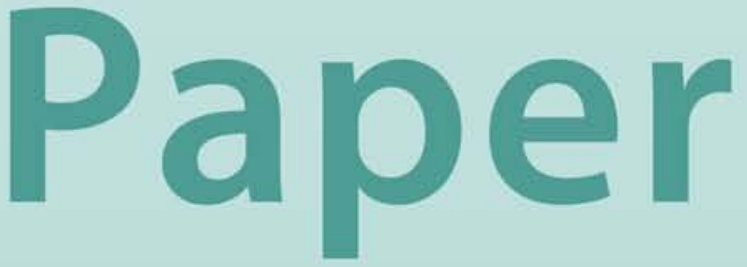




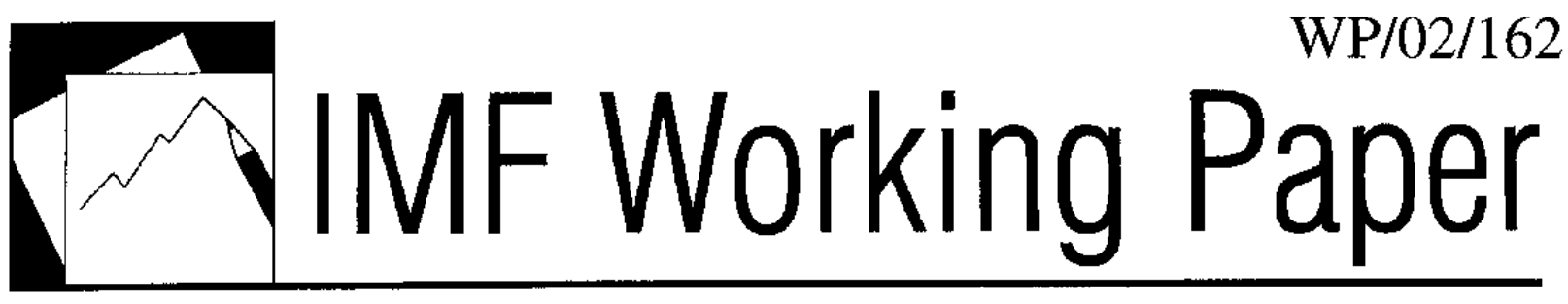

Politics, Government Size, and Fiscal Adjustment in Industrial Countries

Anthony Annett 


\title{
IMF Working Paper
}

Fiscal Affairs Department

\section{Politics, Government Size, and Fiscal Adjustment in Industrial Countries}

\author{
Prepared by Anthony Annett ${ }^{1}$ \\ Authorized for distribution by Richard Hemming
}

September 2002

\begin{abstract}
The views expressed in this Working Paper are those of the author(s) and do not necessarily represent those of the IMF or IMF policy. Working Papers describe research in progress by the author(s) and are published to elicit comments and to further debate.
\end{abstract}

It is now well established that political and institutional factors matter for fiscal outcomes. Following a review of the literature, this paper examines the relationship between a variety of political-institutional variables and fiscal aggregates-encompassing the overall balance as well as expenditure and revenue and their various components-across 19 industrial countries over the past two decades. It finds strong effects on fiscal policy from such factors as type of electoral system, degree of legislative or government fragmentation, and stability of government. Some of the strongest results emerge for certain components of expenditure, such as transfers, and for the balance between labor and consumption taxation. There are clear relationships between the type of political system and choice of tax and expenditure system. The paper also examines fiscal adjustment since the late 1980s in light of these political factors, finding some evidence of a reversal in trend, but only when growth has been high or when debt has become problematic.

JEL Classification Numbers: E62; H60.

Keywords: Fiscal Policy; Political Economy.

Author's E-Mail Address: aannett@imf.org

\footnotetext{
${ }^{1}$ I thank Marco Cangiano, Richard Hemming, Philip Lane, and Axel Schimmelpfennig for providing constructive comments, as well as Alfredo Baldini and Gian Maria Milesi-Ferretti for supplying their data.
} 


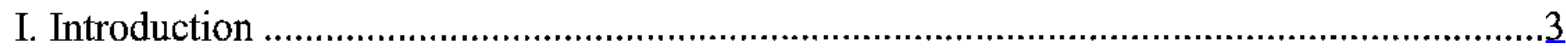

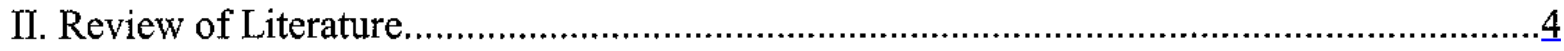

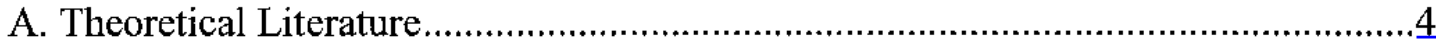

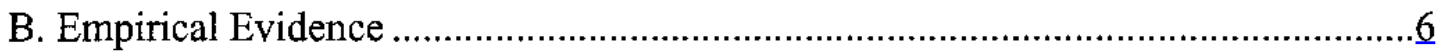

C. Recent Institutional Developments ...................................................................

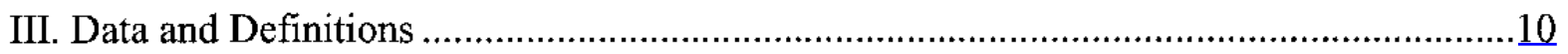

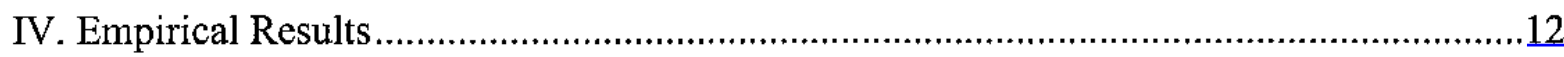

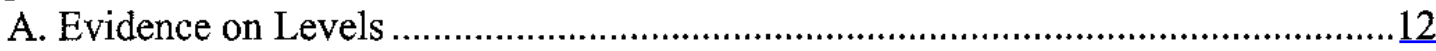

B. Evidence on Adjustment .................................................................................

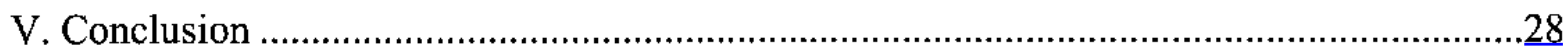

Text Tables

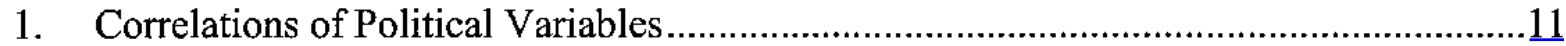

2a. Expenditure Levels, Fiscal Balance, and Political Variables ..........................................13

2b. Expenditure Levels, Fiscal Balance, and Political Variables ........................................16

3a. Revenue and Political Variables ..............................................................................

3b. Revenue and Political Variables ...............................................................................19

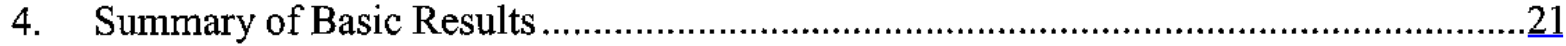

5. Fiscal Adjustment, Growth, and Political Variables.....................................................24

6. Fiscal Adjustment, Initial Debt, and Political Variables..................................................26

Appendix

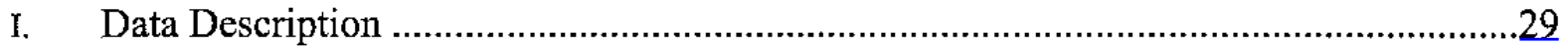

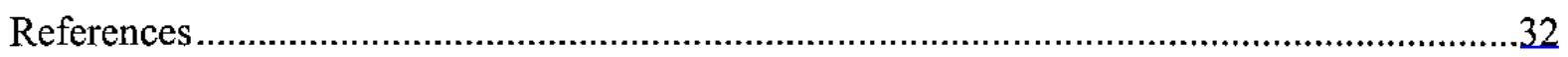




\section{INTRODUCTION}

Different industrial countries have had widely different fiscal experiences in terms of size of government, composition of revenue and expenditure, and size of fiscal balance. Exploring some of these differences, Alesina and Perotti (1995a) were not satisfied with prevailing economic explanations - based on tax smoothing premises-for budget deficits. In particular, they argued that different experiences with the size and persistence of budget deficits across countries and across different time periods pointed toward political and institutional dimensions.

Alesina and Perotti were motivated by the experience with large public deficits across certain industrial countries in the 1970s and 1980s. Since then, with the exception of Japan, fiscal positions in industrial countries have improved substantially. The average general government budget deficit in the sample of 19 industrial countries analyzed in this paper declined from over $41 / 2$ percent in the first half of the 1990 s to $13 / 4$ percent by the second half. ${ }^{2}$ Two distinct periods of adjustment can be distinguished: an earlier phase in the mid-1980s and a later phase in the second half of the $1990 \mathrm{~s}$, separated by a period of expansion triggered by the economic slowdown of the early 1990s (International Monetary Fund, 2001). The early period relied more on revenue increases, while the adjustment in the 1990s was more focused on cutting expenditure. Between the first and second halves of the 1990s, the expenditure ratio fell by nearly $2 \frac{1}{2}$ percentage points, back to the level of 1980 . While falling debt and lower interest rates led to a reduction in interest payments, fiscal adjustment has consisted mainly of a reduction in primary expenditure. Much of this adjustment took place through cutting government wages and transfers, the main causes of the earlier trend increase in government size. During this period, the revenue ratio increased by only half a percentage point of GDP, compared with the $1980 \mathrm{~s}$, when it rose by over $2 \frac{1}{2}$ percentage points from the first half to the second half of the decade.

Although the recent bout of adjustment has led to some convergence of fiscal policy (Fatas and Mihov, 2001; Hallerberg, 2001), substantial cross-country differences remain. While the average size of government, measured by the ratio of total expenditure to GDP, was 45 percent in the late 1990s, this varied between 58 percent in Sweden and 31 percent in the United States. A similar variation is evident for revenue and for the different categories of revenue and expenditure. So even if deficits converge, the size and composition of government can still be very different across countries. Any political or institutional explanation for fiscal policy needs to account for this.

This paper tackles two key questions. First, can political or institutional factors shed any light on the observed differences in size and composition of government revenue and expenditure that still prevail among industrial countries, as well as differences in the overall budget balance? Second, can these same factors help explain the recent pattern of fiscal consolidation, both in its size and composition? The answer to both questions is yes. The paper is organized as follows: Section II provides a general review of the literature pertaining to the political economy of fiscal

\footnotetext{
${ }^{2}$ All numbers are simple averages for industrialized OECD countries.
} 
policy; Section III describes the data; Section IV contains the econometric results; and Section V concludes.

\section{REVIEW OF LITERATURE}

\section{A. Theoretical Literature}

As noted at the outset, it has become increasingly common to appeal to political factors as an explanation of fiscal outturns in industrial countries. Different theories of political behavior offer different predictions for the size of government and for the deficit (or debt). ${ }^{3}$ Much research focuses on distributional conflict, as will this paper.

\section{Common pool models}

Many theories of distributional conflict in fiscal policy rely on some variant of the "common pool" model, whereby society is divided into competing groups, none of which has an incentive to constrain its spending demands. Such an approach fits easily with the distributional conflicts inherent in fiscal policy. This approach has a number of implications:

- If allegiances are geographical, with the benefits of spending accruing to each constituency but with all constituencies paying for an equal share of the total budget (in taxes), then no single district has the incentive to constrain its spending demands and the size of the government is larger than optimal (Weingast, Shepsle, and Johnsen 1981). The effect of excessive spending on the tax burden is not internalized. Similar models of pork barrel spending are developed in Chari and Cole (1993) and Chari, Jones, and Marimon (1997).

- $\quad$ Conflicts between different social groups can lead to a build up of debt and delay the adoption of certain adjustment measures in the face of a negative shock. Velasco (1999) presents a dynamic common pool model in which the government is dominated by influential interest groups, each deriving utility from a particular type of government spending, but is weak overall. As a result, a deficit bias emerges, and debt is incurred. The model also explains why stabilizations are delayed, as groups will only coordinate when debt reaches a sufficiently high level, reflecting increasingly limited government resources. Alesina and Drazen (1991) present a model of delayed stabilization as different interest groups engage in a war of attrition over who will bear the costs of adjustment.

- $\quad$ Spending ministers fail to internalize the costs of financing spending on society as a whole, and this weakness is more pronounced in countries with poor budgetary institutions (von Hagen 1992, Von Hagen and Harden 1996). Coordination can entail either delegation, where the finance minister has strong agenda setting power and the

\footnotetext{
${ }^{3}$ Recently, a number of works have emerged presenting general overviews of the literature, including Persson and Tabellini (2000a) and Drazen (2000).
} 
legislature is relatively weak, or the contracts approach, where all members of the executive must agree to binding targets, and the legislature assumes a greater monitoring role. Both solutions serve to internalize the externalities associated with the common pool problem.

- Some studies trace fiscal indiscipline to the type of government generated by the electoral system. A number of different hypotheses need to be distinguished: (i) some argue that coalition governments, typical under proportional electoral systems, are associated with larger deficits and have a harder time adjusting to negative shocks and initiating a successful fiscal adjustment. This is because each party has its own vested interests and enforcement mechanisms are weak (Roubini and Sachs 1989, Spolaore 1993, Alesina and Perotti, 1995b); (ii) others claim that proportionality leads to shorter government duration, and the associated political instability is associated with worse fiscal outcomes (Grilli, Masciandaro, and Tabellini, 1991; de Haan and Sturn, 1994); (iii) another variant says that it is more difficult to uphold centralizing budgetary institutions in multiparty governments. Coalition governments are more suited to the contracts approach, where the risk of bringing down the government can maintain discipline. Ultimately it is the inability to enforce a contracts approach to budgetary centralization within a multiparty coalition, which leads to a lack of fiscal discipline (Hallerberg and von Hagen, 1999).

\section{Electoral system models}

Another related strand in the literature identifies the underlying incentives generated by the different electoral systems - typically majoritarianism and proportionality - as a key source of fiscal variation. This approach tends to focus on the composition of government expenditure rather than the fiscal balance.

Persson and Tabellini (2000a) argue that the smaller the electoral district, the more electoral competition focuses on narrower geographical interests. Politicians must please a large number of voters when the district is large. Hence proportional systems with large districts should lead to more general provision of public goods, while majoritarian systems should encourage targeted redistribution (either transfers or local public goods).

Lizzeri and Persico (2000a) maintain that public goods will be under-provided as it is easier for politicians to win votes by targeting expenditures. A proportional system is more efficient when the public good is more valuable. This is because the margin of victory matters more in proportional systems, and the margin of victory for a candidate choosing transfers over the public good declines as the public good becomes more valuable.

Lizzeri and Persico (2000b) relate the number of parties to fiscal policy outcomes. They argue that since a larger number of parties means that each party will win a smaller fraction of the vote, parties will focus more on targeted transfers. So a higher number of parties in the electoral system leads to higher transfers and lower public goods provision. Austin-Smith (2000) also claims that a larger number of parties, reflecting more proportional electoral systems, leads to higher redistributive tax rates than two-party systems. 
Milesi-Ferretti, Perotti, and Rostagno (2001) assume that transfers are targeted to social groups (such as pensioners and the unemployed) and public goods are targeted on a geographical basis. They argue that in a majoritarian system, assuming that the distribution of social groups is the same across geographical districts, all elected representatives will belong to the same social group. Hence, voters will choose legislators with stronger preferences for public goods over transfers. In proportional systems with large district size, representatives of different social groups will be elected to parliament. In this situation, individuals have an incentive to vote for legislators with stronger preferences for transfers, so that they can bias government spending towards their own favored type of transfer. The model predicts that spending on transfers is higher in proportional systems, and spending on public goods is higher in majoritarian systems.

\section{B. Empirical Evidence}

\section{Instability and fragmentation}

Many studies have analyzed the relationship between political variables and the budget deficit among industrial countries. In an early contribution, Roubini and Sachs (1989) argue that government weakness leads to higher deficits in a cross section of industrial countries between 1960-85. These results have subsequently been criticized: Edin and Ohlsson (1991) argue that they are being driven by minority governments, while de Haan and Sturm (1994) and de Haan, Sturm, and Beekhuis (1999) find no effect of this variable on the budget deficit between 197995. In a study of 15 industrial countries from 1950-89, Grilli, Masciandaro, and Tabellini (1991) find that fiscal indiscipline-high deficits and debt - is typically associated with proportional electoral systems and the culprit seems to be short government duration. De Haan and Sturm (1994) reach a similar conclusion, arguing that the frequency of government change affected government debt growth in the 1980s.

A large subset of the literature emphasizes the importance of government fragmentation. De Haan, Sturm, and Beekhuis (1999) find that the number of parties in government is important for explaining government debt. Skilling (2001) shows that unlike single-party governments, coalition governments tend to loosen fiscal policy in good times. Kontopoulos and Perotti (1999) maintain that the key political determinant of the deficit is executive fragmentation (defined as the number of spending ministries) as opposed to legislative fragmentation (defined as the number of parties in the coalition). However, executive fragmentation seemed to matter more in the $1970 \mathrm{~s}$, while legislative fragmentation was important in the 1980s. Bradbury and Crain (2001) focus instead on the size of the legislature and provide cross-country evidence that the size of the lower chamber increases government spending, while the size of the upper chamber reduces it; they argue that bicameralism mitigates the common pool problem. Alesina and Perotti (1995b) and Alesina, Perotti, and Tavares (1998) show that while coalition governments implement fiscal tightening as often as single-party governments, the probability of successfully reducing the budget deficit is lower. They argue that successful fiscal consolidation requires cutting government wages and transfers, both of which benefit some of the most entrenched vested interests in a country, and that the nature of a coalition makes such an adjustment difficult. Alesina and Perotti (1995b) also show that minority governments are also equally likely to undertake adjustment, and contrary to the findings for coalitions, are likely 
to be successful, even more than for single-party governments. The explanation given here is that minority governments are often caretaker governments with a specific mandate to undertake fiscal adjustment.

\section{Budgetary institutions}

In terms of budgetary institutions, there is ample evidence of a link between budgetary centralization and fiscal outturns. For the EU, a number of studies show a significant correlation between the degree of budgetary centralization and fiscal outturns, defined in terms of expenditure, deficits, and debt (Von Hagen, 1992; De Haan and Sturm 1994; and von Hagen and Harden, 1994, 1995, 1996). The results are based on the construction of an index taking into account the most pertinent features of the budgetary process, emphasizing: a strong finance minister in negotiations over the size of the budget; a parliamentary process with limits on amendments, and line-by-line votes on expenditure combined with a global vote on the budget proceeding debate; a large degree of transparency; and limited flexibility and a strong role for the minister of finance in execution. Skilling (2001) shows that budgetary centralization can prevent fiscal profligacy in good times. Alt, Lassen, and Skilling (2000) construct an index of transparency for 19 countries, and show that transparency has a positive effect on fiscal outcomes; this effect is mitigated, however, when political competition is high.

Budgetary institutions have been shown to matter in other parts of the world. For U.S. states, Poterba (1994), Alt and Lowry (1994), Reuben (1995), Alesina and Bayoumi (1996), Bohn and Inman (1996), Knight and Levinson (2000), and Strauch (2000) have shown that states with stronger budgetary institutions are associated with more favorable fiscal outcomes. Alesina, Hausmann, Hommes, and Stein (1999) show that countries with more hierarchical and transparent procedures are associated with greater fiscal discipline in Latin America. Stein, Talvi, and Grisanti (1999) also find that more transparent and more hierarchical procedures lead to lower deficits and debt in Latin America.

\section{Electoral rules}

Some recent research has focused on the empirical relationship between electoral rules and the size and composition of government spending. Using a panel of 61 democracies from the $1960 \mathrm{~s}$ through the 1990s, Persson and Tabellini (2000b) find that the size of government is smaller (especially revenue) and spending on social security and welfare is lower under majoritarian systems. Employing data for 20 OECD and 20 Latin American countries, Milesi-Ferretti, Perotti, and Rostagno (2001) find that proportional systems are associated with higher spending on transfers. This result is especially strong in OECD countries. ${ }^{4}$ In the context of Latin America, Stein, Talvi, and Grisanti (1999) find that countries with a higher degree of

\footnotetext{
${ }^{4}$ In the context of explaining the different levels of transfers in the United States and Europe, Alesina, Glaeser, and Sacerdote (2001) point to the disproportionality in the U.S. political system, as well as to the degree of racial fragmentation in the United States, where a disproportionate number of members of minorities are beneficiaries of the welfare state. In regression analysis, they find that an index of racial fractionalization is negatively related to transfers.
} 
proportionality and a large degree of political fragmentation have bigger government, bigger deficits, and more procyclical fiscal policy. Scartascini and Crain (2001) argue that a higher number of effective political parliamentary parties is associated with bigger government, higher transfers and lower public goods provision across a broad spectrum of countries.

\section{Partisan effects}

The evidence for partisan effects on fiscal policy is weak. Alesina, Roubini, and Cohen (1997) find no evidence that left-wing governments in industrial countries lead to higher deficits. Alesina and Perotti (1995b) and Alesina, Perotti, and Tavares (1998) argue that left-wing and right-wing governments are equally likely to undertake successful fiscal adjustment and that ideology has no effect on the frequency of loose and tight episodes. Indeed, ideologically centrist governments are often more likely to engage in loose fiscal policy, and less likely to achieve a successful consolidation. They argue that this reflects the fact that most centrist governments are made up of coalitions with differing interests. De Haan and Sturm (1994) do find that left wing governments are associated with larger government.

\section{Recent Institutional Developments}

To curb the expenditure and deficit pressures brought about the various political inefficiencies, industrial countries have turned recently towards institutional reforms, such as adopting fiscal rules or binding fiscal targets, improving fiscal transparency, and implementing budgetary reform (Hemming and Kell, 2001).

This development stems from a growing awareness of the deep-rooted costs of profligate fiscal policy, for a number of reasons. First, countries recognized the need to attain long-term fiscal sustainability especially in light of growing demands for pension and health care spending in the future. Second, it became increasingly apparent that the typical fiscal policy mix, combining high transfers with a heavy tax burden on labor, was creating supply-side problems, given evidence that labor taxation and high tax wedges are detrimental to growth (Bleaney, Gemmell, and Kneller 2000) and employment (Blanchard and Wolfers 1999, Nickell and Layard 1999); this is especially true for continental Europe where unions can shift the burden of labor taxes to firms (Alesina and Perotti 1997a, Daveri and Tabellini 2000). Third, evidence suggested that fiscal adjustments based on cuts in government wages and transfers tended to be more durable, and that they were associated with better macroeconomic performance (Alesina and Perotti, 1997b).

Drawing a parallel with monetary policy, many have argued that to prevent the emergence of deficit or expenditure biases, fiscal policy should be guided more by rules than discretion. Industrial countries have adopted a diverse set of fiscal rules and frameworks. ${ }^{5}$ For euro area countries, the most prominent examples are the Maastricht Treaty and the Stability and Growth Pact (SGP), which require countries to maintain structural fiscal positions of close to balance or in surplus and for fiscal deficits not to exceed 3 percent of GDP. Other countries committed

\footnotetext{
${ }^{5}$ See Hemming and Kell (2001) for an overview.
} 
themselves to balanced budgets over the cycle (Australia, New Zealand, Switzerland) or by certain dates (Canada, the United States). Some countries, including Sweden, Finland, Netherlands, and the United States impose expenditure rules. The United Kingdom operates a golden rule (borrowing only to finance capital spending) and a sustainable investment rule (which limits debt to 40 percent of GDP) over the cycle. Other debt rules include the Maastricht 60 percent target (in the build up to monetary union), and those adopted by Australia, New Zealand, Canada, and Sweden.

In tandem with this development, a number of countries also made changes to budget institutions in the 1990s. Australia, New Zealand and the United Kingdom all emphasized the importance of fiscal transparency, and developed fiscal frameworks accordingly. A number of countries in the EU-including Ireland, Austria, Sweden, Belgium, Spain, and Italy-undertook budgetary reforms during the 1990s, often using Maastricht as a justification (von Hagen, Hughes Hallett, and Strauch, 2000). The need for reform was particularly acute in Belgium and Italy, two countries with some of the worst fiscal outcomes in the OECD at the onset of the last decade (Hallerberg, 2000). As well as strengthening the position of the finance minister, Italy made a significant change to its political system, moving away from proportionality in an attempt to reduce instability and fragmentation. ${ }^{6}$ One exception to this centralizing trend is Germany, where budgetary institutions actually weakened over the past decade, helping to explain its weakening fiscal position (von Hagen and Strauch, 1999).

It is difficult to assess the contribution of fiscal rules to adjustment, absent institutional factors. Kennedy, Robbins, and Delorme (2000) argue that fiscal rules are not necessary for consolidation. Brumby and Cangiano (2001) maintain that the recent wave of expenditure-based adjustment is likely to prove more durable than in the past given that it has been accompanied by deep rooted public expenditure management reforms. Within the EU, von Hagen, Hughes Hallett, and Strauch (2000) argue that the SGP is more suited to countries for which the contracts (as opposed to the delegation) approach to budgetary centralization is the appropriate one, given its reliance on multi-annual targets and regular reviews. For the United States, von Hagen and Harden (1996) stress that, given its majoritarian nature, the target-oriented approach of the Gramm-Rudman-Hollings Act of 1985 was far less successful in controlling the deficit than the Budget Enforcement Act of 1990, which relied more on procedures. Hallerberg, Strauch, and von Hagen (2001) maintain that while rules matter, the efficacy of rules depends crucially on institutional design.

This paper is motivated by these recent institutional developments, as well as some omissions from the current research. For a start, although some of the recent electoral rule literature addresses the composition of government spending, most current research focuses on the overall balance. It is not obvious why political factors should influence the overall balance more than

\footnotetext{
${ }^{6}$ Other countries made some changes to their electoral systems over the past two decades. France undertook a major change in 1986, moving from plurality to proportional representation, but switched back two years later. New Zealand also switched its system from their British-style first-past-the-post majoritarianism to proportional representation in a 1993 referendum which significantly affected politics in the late 1990s. The effective number of parliamentary parties increased from 1.7 in 1991 to 3.7 in 1999. Greece also made some minor changes, but the size of electoral districts remained small.
} 
the size and composition of government spending or taxation. Much of the existing literature was motivated by the high deficits in the $1970 \mathrm{~s}$ and $1980 \mathrm{~s}$, and does not deal with the adjustment of the 1990s. The present paper addresses not only the effects of political factors on fiscal outturns but also the relationship between these same political variables and the size and quality of fiscal adjustment undertaken. The time period under consideration extends from the early 1980 s through the late 1990 s. Finally, this paper categorizes political variables into three distinct categories - representing the type of electoral system, the fragmentation of policymaking, and the degree of political instability-and analyzes the effect of each type of variable on fiscal outturns.

\section{Data And Definitions}

The following 19 countries are included in the analysis: Australia, Austria, Belgium, Canada, Denmark, France, Finland, Germany, Greece, Ireland, Italy, Netherlands, New Zealand, Norway, Portugal, Spain, Sweden, the United Kingdom, and the United States. For each country, the variables will be defined as five-year averages of the following periods: $1980-84$, 1985-89, 1990-94, and 1995-99; the idea here is to allow for a smoother data series. The basic econometric technique is pooled OLS with period dummies, although fixed and random effects models are also considered.

This paper experiments with a number of different political variables along a few basic dimensions in an effort to understand the importance of each in explaining fiscal policy across countries. A detailed description of each variable is provided in Appendix 1.

First, theory suggests that the salient features of the electoral system-typically the difference between proportionality and majoritarianism - matter for fiscal policy. Majoritarian systems usually combine small district size with plurality (whereby the party with the highest vote gets the seat). In contrast, proportional systems tend to have large district sizes, and use proportional representation to apportion seats. The United States and United Kingdom represent the extreme majoritarian case, with one representative elected per district on a first-past-the-post system, while the Netherlands is at the other extreme, with a single nationwide electoral district and seats being assigned based on vote share.

Thus there are two dimensions along which proportionality can be measured: how votes are turned into seats, and the average district size. In terms of the former, two standard indices of disproportionality are used, the square root of the sum of squares of the deviations between vote and seat percentages $(L S Q)$ and the average of the deviations (in absolute values) of the shares of electoral votes of each party from its share of seats $(R A E)$. These indices attempt to capture the extent to which the percent of votes received differs from the percent of seats won for each party, with a higher value indicating larger disproportionality. $L S Q$ gives more weight to larger deviations than does $R A E$. As indicated in Table 1, these variables are highly correlated. The second dimension of the electoral system is measured by the log of the average district size ( $L A M)$; the average magnitude ranges from 1 for majoritarian countries such as the United Kingdom and United States to 150 for the Netherlands. It is highly correlated with the ex post measures of proportionality, $L S Q$ and $R A E$. 
Table 1. Correlations of Political Variables

\begin{tabular}{|c|c|c|c|c|c|c|c|c|c|c|c|}
\hline & $L S Q$ & $R A E$ & $L A M$ & ENEP & ENPP & ENGP & $N O P$ & NOM & NUMGOVT & NUMELEC & AVDURAT \\
\hline$L S Q$ & 1.00 & & & & & & & & & & \\
\hline$R A E$ & 0.89 & 1.00 & & & & & & & & & \\
\hline$L A M$ & -0.75 & -0.82 & 1.00 & & & & & & & & \\
\hline ENEP & -0.19 & -0.37 & 0.36 & 1.00 & & & & & & & \\
\hline$E N P P$ & -0.41 & -0.53 & 0.50 & 0.97 & 1.00 & & & & & & \\
\hline$E N G P$ & -0.37 & -0.45 & 0.46 & 0.88 & 0.91 & 1.00 & & & & & \\
\hline$N O P$ & -0.37 & -0.46 & 0.46 & 0.79 & 0.82 & 0.89 & 1.00 & & & & \\
\hline NOM & 0.40 & 0.26 & -0.21 & 0.03 & -0.06 & -0.13 & 0.07 & 1.00 & & & \\
\hline NUMGOVT & -0.18 & -0.21 & 0.13 & 0.18 & 0.20 & 0.20 & 0.41 & 0.39 & 1.00 & & \\
\hline NUMELEC & -0.24 & -0.07 & -0.02 & -0.15 & -0.06 & -0.01 & -0.06 & -0.17 & 0.39 & 1.00 & \\
\hline AVDURAT & 0.20 & 0.20 & 0.00 & -0.11 & -0.14 & -0.10 & -0.27 & -0.23 & -0.82 & -0.34 & 1.00 \\
\hline
\end{tabular}

The second set of political variables relates directly to the number and strength of different players, and measures the degree of fragmentation in policymaking. One basic variable is the number of parties in government $(N O P)$, representing coalition size. Other variables attempt to measure the relative strength of the parties, based on their relative sizes. The effective number of electoral parties $(E N E P)$ measures fragmentation by looking at the effective number of parties who stand for election, weighted by vote share. A more likely variant is the effective number of parliamentary parties (ENPP), which considers parties with seats in the legislature. ${ }^{7}$ A third variant under consideration, the effective number of parties in government $(E N G P)$, applies the same methodology to coalition parties. It is closely related to $N O P$, but takes into account the relative strength of each governing party. These measures are all fairly highly correlated with each other, but only moderately correlated with the proportionality variables. Another variable in this class is the number of government ministers (NOM); a higher number could reflect more spending pressures. However, this variable is weakly correlated with the other fragmentation variables, suggesting an entirely different dimension of fragmentation.

The third set of variables relates the to frequency of government change within each five-year period. One basic indicator counts the number of governments, which held office within a given five-year period in a country (NUMGOVT). Governments can terminate for any number of reasons, including legally mandated elections, resignation of the prime minister, dissent within government, lack of parliamentary support, of intervention by the head of state. Not all government collapses end in elections; in fact, typically they do not. A second variable counts the number of elections within each five-year period in each country (NUMELEC), on the grounds that frequent elections may be more unstable than mere frequent government changes. The correlation between NUMGOVT and NUMELEC is small. Finally, another measure of instability is the average duration in months of each government within each five-year period in each country ( $A V D U R A T)$. AVDURAT is strongly correlated with $N U M G O V T$. These variables

\footnotetext{
${ }^{7}$ This measure would assign a value of $N$ to $N$ equally-sized parties. If, however, some of these parties are weaker than others, the value will be less than $N$. See Lijphart (1994).
} 
are only weakly correlated with both the proportionality and fragmentation variables, suggesting yet another clear political dimension.

Government ideology (IDEOL) is also taken into account. Based on Woldendorf, Keman, and Budge (2000), IDEOL is a variable on the scale of 1 to 5, with 1 being the most right wing, and 5 being the most left wing government.

Finally, the effects of ethnolinguistic fractionalization (ELFRAC) within a country are considered. At least some studies argue that this has an effect on the composition of government spending. This variable is constant over time.

\section{EMPIRICAL RESULTS}

\section{A. Evidence on Levels}

\section{Methodology}

The methodology used is to regress each fiscal variable, expenditure and revenue, as well as their major components, on a number of control variables combined with the political variables. The log of real GDP per capita is used to control for a "Wagner's Law" effect whereby richer countries choose bigger governments. The log of population is also included to take account of size effects; Alesina and Wacziarg (1998) show that country size is negatively related to government size reflecting the economies of scale in providing public goods in large countries. Finally, the percent of the population over 65 is included to account for demographic factors, which is especially important when it comes to transfers.

The political variables described in the last section are classified into three distinct groups: the electoral system $(R A E, L S Q, L A M)$, policymaker fragmentation (NOP, NOM, ENEP, ENPP, $E N G P$ ), and political instability (NUMGOVT, NUMELEC, AVDURAT). Further, the effects of ideology and ethnolinguistic fractionalization, reflecting divisions in the populace rather than among policymakers, will also be considered. For the sake of robustness, the tables also make reference to those related variables, which would have significant coefficients if they replaced the variable of interest, and to the variables with significant coefficients if the equations were estimated using fixed and random effects.

\section{Expenditure and overall balance}

Tables $2 \mathrm{a}$ and $2 \mathrm{~b}$ focus on expenditure, as well as the overall balance. The first four columns of Table $2 \mathrm{a}$ report regressions of total expenditure on the control variables and political variables of interest. In general, the economic variables have the predicted signs and significance, as richer, smaller, and "older" countries all tend to have bigger governments. There is some evidence that a more disproportional electoral system (RAE and $L A M)$ is associated with larger government. Moreover, both large coalitions $(N O P)$ and large cabinets $(N O M)$ are associated with bigger governments. Instability also matters: longer-lasting governments (AVDURAT) tend to have lower expenditure ratios. On the flip side, a larger number of governments gives rise to bigger government. However, the number of elections does not affect expenditure; it is the 
Table 2a. Expenditure Levels, Fiscal Balance, and Political Variables

\begin{tabular}{|c|c|c|c|c|c|c|c|c|}
\hline $\begin{array}{l}\text { Dependent } \\
\text { Variable }\end{array}$ & $\begin{array}{r}(1) \\
\text { TOTEXP }\end{array}$ & $\begin{array}{r}(2) \\
\text { TOTEXP }\end{array}$ & $\begin{array}{r}(3) \\
\text { TOTEXP }\end{array}$ & $\begin{array}{r}(4) \\
T O T E X P\end{array}$ & $\begin{array}{r}(5) \\
\text { TRAN }\end{array}$ & $\begin{array}{r}(6) \\
\text { TRAN }\end{array}$ & $\begin{array}{r}\text { (7) } \\
\text { TRAN }\end{array}$ & $\begin{array}{r}(8) \\
T R A N\end{array}$ \\
\hline$L R G D P$ & $\begin{array}{r}11.59 \\
(3.73)\end{array}$ & $\begin{array}{r}6.16 \\
(1.98)\end{array}$ & $\begin{array}{r}6.30 \\
(1.80)\end{array}$ & $\begin{array}{r}6.47 \\
(2.05)\end{array}$ & $\begin{array}{r}3.03 \\
(2.03)\end{array}$ & $\begin{array}{r}0.79 \\
(0.59)\end{array}$ & $\begin{array}{r}2.54 \\
(1.68)\end{array}$ & $\begin{array}{r}0.86 \\
(0.65)\end{array}$ \\
\hline$\angle P O P$ & $\begin{array}{r}-0.88 \\
(-1.32)\end{array}$ & $\begin{array}{r}-2.10 \\
(-4.41)\end{array}$ & $\begin{array}{r}-2.37 \\
(-4.04)\end{array}$ & $\begin{array}{r}-2.05 \\
(-3.84)\end{array}$ & $\begin{array}{r}-0.30 \\
(-0.82)\end{array}$ & $\begin{array}{r}-0.73 \\
(-2.69)\end{array}$ & $\begin{array}{r}-0.53 \\
(-1.87)\end{array}$ & $\begin{array}{r}-0.60 \\
(-2.11)\end{array}$ \\
\hline POP65 & $\begin{array}{r}1.64 \\
(4.11)\end{array}$ & $\begin{array}{r}1.93 \\
(6.37)\end{array}$ & $\begin{array}{r}2.26 \\
(6.32)\end{array}$ & $\begin{array}{r}1.67 \\
(4.39)\end{array}$ & $\begin{array}{r}0.93 \\
(5.14)\end{array}$ & $\begin{array}{r}1.12 \\
(6.91)\end{array}$ & $\begin{array}{r}1.11 \\
(6.18)\end{array}$ & $\begin{array}{r}0.98 \\
(6.07)\end{array}$ \\
\hline$R A E$ & $\begin{array}{r}-0.77 \\
(-2.01)\end{array}$ & & & $\begin{array}{r}-0.57 \\
(-1.45)\end{array}$ & $\begin{array}{r}-0.44 \\
(-2.29)\end{array}$ & & & $\begin{array}{r}-0.31 \\
(-1.78)\end{array}$ \\
\hline NOM & & $\begin{array}{r}0.32 \\
(2.72)\end{array}$ & & $\begin{array}{r}0.39 \\
(2.68)\end{array}$ & & $\begin{array}{r}0.08 \\
(1.12)\end{array}$ & & $\begin{array}{r}0.08 \\
(1.37)\end{array}$ \\
\hline$N O P$ & & $\begin{array}{r}1.35 \\
(2.99)\end{array}$ & & $\begin{array}{r}0.85 \\
(1.49)\end{array}$ & & $\begin{array}{r}0.8 \\
(3.37)\end{array}$ & & $\begin{array}{r}0.47 \\
(1.68)\end{array}$ \\
\hline$A V D U R A T$ & & & $\begin{array}{r}-0.10 \\
(-1.99)\end{array}$ & $\begin{array}{r}-0.04 \\
(-1.75)\end{array}$ & & & $\begin{array}{r}-0.06 \\
(-2.37)\end{array}$ & $\begin{array}{r}-0.05 \\
(-1.99)\end{array}$ \\
\hline$I D E O L$ & $\begin{array}{r}-1.16 \\
(-1.15)\end{array}$ & & & & $\begin{array}{r}-0.09 \\
(-0.15)\end{array}$ & & & \\
\hline ELFRAC & & & $\begin{array}{r}2.88 \\
(0.80)\end{array}$ & & & & $\begin{array}{r}-3.55 \\
(-2.46)\end{array}$ & \\
\hline$R^{2}$ & 0.53 & 0.60 & 0.54 & 0.62 & 0.55 & 0.61 & 0.61 & 0.65 \\
\hline NOBS & 66 & 70 & 70 & 70 & 66 & 70 & 70 & 70 \\
\hline Robust to: & $L A M$ & $\begin{array}{l}\text { ENEP } \\
\text { ENPP } \\
\text { ENGP }\end{array}$ & NUMGOVT & $\begin{array}{c}L A M^{*} \\
E N E P^{*} \\
E N P P^{*}\end{array}$ & $L A M$ & $\begin{array}{l}\text { ENPP } \\
\text { ENGP }\end{array}$ & NUMGOVT & $\begin{array}{r}\text { LAM } \\
\text { NUMGOVT }\end{array}$ \\
\hline Fixed effects: & & $\begin{array}{c}E N E P(-) \\
E N P P(-)\end{array}$ & $A V D U R A T$ & $\begin{array}{r}\text { AVDURAT } \\
\text { ENEP(-) } \\
\text { ENPP (-) }\end{array}$ & & $E N P P(-)$ & AVDURAT & $\begin{array}{r}\text { AVDURAT } \\
\text { ENEP(-) } \\
\text { ENPP (-) }\end{array}$ \\
\hline Random effects: & $L A M$ & & $\begin{array}{l}\text { AVDURAT } \\
\text { NUMGOVT }\end{array}$ & AVDURAT & $\begin{array}{l}L A M \\
R A E\end{array}$ & NOP & $\begin{array}{l}\text { AVDURAT } \\
\text { NUMGOVT }\end{array}$ & $\begin{array}{r}L A M \\
\text { AVDURAT } \\
\text { NUMGOVT }\end{array}$ \\
\hline
\end{tabular}

Notes: All equations include time dummies. Robust standard errors. $t$-statistics in parentheses.

* Significant if included instead of standard variable. 
instability engendered by all changes of government, not just following elections, that matters. Ideology does not seem to matter at all; this is consistent with past results. The coefficient on ethnolinguistic fractionalization is also insignificant.

Of course, the importance of each set of political variables may not reflect competing effects, given the correlations between variables. Hence any results from an equation including a large number of political variables simultaneously should be interpreted cautiously. Column 4 undertakes such an exercise with $R A E, N O M, N O P$, and $A V D U R A T$ all included in the same equation. The results are inconclusive: while the coefficients on $R A E$ and NOP lose significance in this regression, this would not happen if $L A M$ was used to measure proportionality and either ENEP or ENPP was used to measure fragmentation. Furthermore, an F-test on these four variables suggests that they are jointly significant, pointing to multicollinearity as a potential problem.

The next four columns of Table $2 \mathrm{a}$ are devoted to transfers. In this context, a fair amount of effort has been devoted to explaining the growth of transfers in political and institutional terms, more so than any other component of expenditure. A primary result is borne out here: more proportional electoral systems (proxied by the manner in which votes are transformed into seats, $R A E$, or by the size of electoral districts, $L A M$ ) tend to give rise to higher levels of transfers. Turning to fragmentation, there is some evidence that larger coalitions are associated with higher transfers. In contrast with the total expenditure results, the size of cabinet does not appear to affect transfers. On the other hand, instability does matter, with shorter-lived governments providing higher transfers. Interestingly, when RAE, NOP, and AVDURAT are included in the same equation (column 8), all are significant with the anticipated sign, signaling that political effects are an extremely important influence on the size of the welfare state. The impact of ethnolinguistic fractionalization on transfers also diverges from its effect on total expenditure: the coefficient is negative and significant, suggesting that transfers are lower in more heterogeneous societies, in line with the findings of Alesina, Glaeser and Sacerdote (2001).

As a further robustness test, the equations for total expenditure and transfers are estimated using fixed and random effects. Caution is needed with the interpretation of these results, given the limited time variation in many of the political variables. The results for the fixed effects estimation are weaker, which is not surprising given that most of the variation in the political variables is across counties rather than across time. A couple of interesting results emerge from the fixed effects estimation. First, longer-lasting governments are associated with smaller expenditure, and smaller transfers. Interestingly, there is much more time variation in the stability variables than in the other political variables. One interpretation of this result is that as governments became more stable in the $1990 \mathrm{~s}$, the size of transfers fell. There is no real evidence that changes in other political variables had such effects over time. Second, in contrast with the OLS results, fixed effects estimation suggests a negative relationship between the effective number of parties and the size of government. This reflects the fact that the effective number of parties increased in some countries over time. ${ }^{8}$ The random effects results are more

\footnotetext{
${ }^{8}$ The low degree of time variation makes this result extremely tentative.
} 
consistent with the OLS ones, with significant roles for proportionality and government stability.

Table $2 \mathrm{~b}$ looks at government wage consumption and the overall balance. The first result of note is that more proportional governments are associated with lower public wage bills, everything else constant (column 1). This fits nicely with the electoral system hypothesis suggesting that majoritarian systems opt for relatively higher spending on public goods. However, there is no evidence that coalitions or fractured legislatures lead to higher government wages. Instead, what seems to matter is cabinet size. Turning to instability, there is some evidence that shorter-lived governments are associated with high wage government consumption. However, by far the most important variable influencing wages is NOM; it is the only remaining significant variable if variables representing the other hypotheses are included. A final interesting result pertains to ethnolinguistic fractionalization: in contrast with transfers, there is some evidence that more divided countries have larger governments, measured by government wages and salaries. This fits with other findings, such as Annett (2001), that more divided countries choose larger governments defined in terms of public goods.

Despite the focus of the existing literature, the results are weaker for the overall balance than for the size of government. A number of results stand out: more proportional electoral systems as well as more fragmented parliaments and governments (especially coalitions) tend to be associated with smaller balances, and a more frequent turnover of governments leads to larger deficits. These results generally confirm previous empirical studies, although they are more fragile and less robust than the expenditure results ${ }^{9}$.

As before, Table $2 b$ includes results of fixed and random effects estimation. For government wage consumption, the results are weaker than for transfers. What stands out (significant in all forms of estimation) is that proportionality-at least as represented by $R A E$-leads to lower government wages. Again, results for the overall balance are weaker, especially for fixed effects.

\footnotetext{
${ }^{9}$ None of the results are significant if the overall balance is replaced by the primary balance.
} 
Table 2b. Expenditure Levels, Fiscal Balance, and Political Variables

\begin{tabular}{|c|c|c|c|c|c|c|c|c|}
\hline Dependent Variable & $\begin{array}{r}(1) \\
W G C\end{array}$ & $\begin{array}{r}(2) \\
W G C\end{array}$ & $\begin{array}{r}(2) \\
W G C\end{array}$ & $\begin{array}{r}(4) \\
W G C\end{array}$ & $\begin{array}{r}(5) \\
B A L\end{array}$ & $\begin{array}{r}(6) \\
B A L\end{array}$ & $\begin{array}{r}(7) \\
B A L\end{array}$ & $\begin{array}{r}(8) \\
B A L\end{array}$ \\
\hline$\angle R G D P$ & $\begin{array}{r}4.98 \\
(5.07)\end{array}$ & $\begin{array}{r}5.10 \\
(5.20)\end{array}$ & $\begin{array}{r}3.70 \\
(3.97)\end{array}$ & $\begin{array}{r}4.93 \\
(4.64)\end{array}$ & $\begin{array}{r}7.47 \\
(2.75)\end{array}$ & $\begin{array}{r}8.55 \\
(3.69)\end{array}$ & $\begin{array}{r}8.93 \\
(3.76)\end{array}$ & $\begin{array}{r}8.56 \\
(3.67)\end{array}$ \\
\hline$\angle P O P$ & $\begin{array}{r}-1.12 \\
(-4.71)\end{array}$ & $\begin{array}{r}-1.20 \\
(-6.25)\end{array}$ & $\begin{array}{r}-1.21 \\
(-5.85)\end{array}$ & $\begin{array}{r}-1.18 \\
(-6.49)\end{array}$ & $\begin{array}{r}-1.16 \\
(-2.35)\end{array}$ & $\begin{array}{r}-1.00 \\
(-3.15)\end{array}$ & $\begin{array}{r}-0.68 \\
(-1.60)\end{array}$ & $\begin{array}{r}-1.08 \\
(-3.25)\end{array}$ \\
\hline POP65 & $\begin{array}{r}0.63 \\
(4.05)\end{array}$ & $\begin{array}{r}0.48 \\
(3.66)\end{array}$ & $\begin{array}{r}0.59 \\
(4.35)\end{array}$ & $\begin{array}{r}0.54 \\
(3.90)\end{array}$ & $\begin{array}{r}0.33 \\
(1.45)\end{array}$ & $\begin{array}{r}0.30 \\
(1.58)\end{array}$ & $\begin{array}{r}0.04 \\
(0.17)\end{array}$ & $\begin{array}{r}0.37 \\
(1.72)\end{array}$ \\
\hline$R A E$ & $\begin{array}{r}0.17 \\
(2.27)\end{array}$ & & & $\begin{array}{r}0.10 \\
(1.04)\end{array}$ & $\begin{array}{r}0.35 \\
(1.80)\end{array}$ & & & $\begin{array}{r}0.19 \\
(1.13)\end{array}$ \\
\hline NOM & & $\begin{array}{r}0.16 \\
(3.99)\end{array}$ & & $\begin{array}{r}0.12 \\
(2.42)\end{array}$ & & $\begin{array}{r}-0.12 \\
(-1.49)\end{array}$ & & $\begin{array}{r}-0.13 \\
(-1.43)\end{array}$ \\
\hline NOP & & $\begin{array}{r}-0.17 \\
(-0.93)\end{array}$ & & $\begin{array}{r}-0.13 \\
(-0.59)\end{array}$ & & $\begin{array}{r}-0.83 \\
(-2.18)\end{array}$ & & $\begin{array}{r}-0.63 \\
(-1.47)\end{array}$ \\
\hline AVDURAT & & & $\begin{array}{r}-0.04 \\
(-1.89)\end{array}$ & $\begin{array}{r}-0.02 \\
(-1.20)\end{array}$ & & & $\begin{array}{r}0.07 \\
(1.88)\end{array}$ & $\begin{array}{r}-0.03 \\
(-0.75)\end{array}$ \\
\hline$I D E O L$ & $\begin{array}{r}-0.28 \\
(-1.03)\end{array}$ & & & & $\begin{array}{r}0.38 \\
(0.63)\end{array}$ & & & \\
\hline ELFRAC & & & $\begin{array}{r}2.67 \\
(1.82)\end{array}$ & & & & $\begin{array}{r}-4.20 \\
(-1.51)\end{array}$ & \\
\hline$R^{2}$ & 0.48 & 0.53 & 0.51 & 0.55 & 0.30 & 0.37 & 0.34 & 0.38 \\
\hline NOBS & 71 & 75 & 75 & 75 & 67 & 71 & 71 & 71 \\
\hline Robust to: & $L S Q$ & & NUMGOVT & & $\begin{array}{l}L S Q \\
L A M\end{array}$ & $\begin{array}{l}E N E P \\
E N P P \\
E N G P\end{array}$ & NUMGOVT & $\begin{array}{l}E N P P^{*} \\
E N G P^{*}\end{array}$ \\
\hline Fixed effects: & $R A E$ & & & $R A E$ & & & & \\
\hline Random effects: & $R A E$ & & & $\begin{array}{r}R A E \\
\text { AVDURAT }\end{array}$ & $L S Q$ & $N O P$ & $\begin{array}{c}\text { AVDURAT } \\
\text { NUMGOVT }\end{array}$ & \\
\hline
\end{tabular}

Notes: All equations include time dummies. Robust standard errors. $t$-statistics in parentheses.

* Significant if included instead of standard variable. 


\section{Revenue}

Tables $3 \mathrm{a}$ and $3 \mathrm{~b}$ presents similar results related to revenue and its decomposition. The literature has paid relatively little attention to the political determinants of the size of government as represented by the revenue side, with few theories as to why revenue should be affected by political factors. The first four columns of Table 3 a report results pertaining to total revenue. As with expenditure, the economic control variables are important: richer and smaller countries, and those with more old people, tend to have higher revenue-GDP ratios. Unlike with expenditure, however, there is little evidence to suggest that political variables matter for revenue. The single exception is that proportionality as measured by the average district magnitude $(L A M)$ does enter in a positive and significant way, suggesting that more proportional governments (at least measured along this single dimension) are associated with higher revenue raising effort. Estimating with fixed effects throws up another interesting result: within countries, more stable governments are associated with lower revenue-GDP ratios. This ties in with the previous resuits, which also saw longer-lasting governments being associated with lower transfers, and a smaller government size.

The remaining columns of Tables $3 a$ and $3 b$ focus on the impact of the standard political variables on the revenue-raising choices facing policymakers. Again, this has received scant attention from the political economy literature. The variables chosen are the shares of labor, capital, and consumption taxation in total revenue. Such decomposition throws up some interesting findings, findings which are masked by focusing on total revenue only.

Regarding the electoral system, there is strong evidence that proportionality leads governments to opt for labor taxation over capital and consumption taxation: the coefficient on $R A E$ is negative and significant for labor taxes (Table 3a, column 5), and positive and significant for the other two main types of taxation (Table $3 \mathrm{~b}$, columns 1 and 5). These results are all robust to the other two definitions of proportionality. One clear pattern is that welfare states are typically financed by taxes on labor, perhaps as part of an implicit social contract between workers and the government. ${ }^{10}$ To this extent, proportional governments will choose high transfers, and finance them with taxes on labor. More majoritarian states do not feel obliged to enter into such a contract, and are more likely to opt for other forms of taxation, especially more efficient consumption taxation. The result also fits the theory of Austin-Smith (2000), that proportional electoral systems have higher redistributive tax rates.

A similar pattern is evident with government fragmentation. There is clear evidence that coalition size $(N O P)$ is associated with higher labor tax shares and lower capital and consumption tax shares. In each case, this result is robust to all of the effective number of parties variables: in elections, parliament, and government (ENEP, ENPP, ENGP). The results

\footnotetext{
${ }^{10}$ The raw correlation coefficient between labor taxes and transfers in this sample is 0.84 .
} 
Table 3a. Revenue and Political Variables

\begin{tabular}{|c|c|c|c|c|c|c|c|c|}
\hline Dependent Variable & $\begin{array}{r}(1) \\
\text { TOTREV }\end{array}$ & $\begin{array}{r}(2) \\
\text { TOTREV }\end{array}$ & $\begin{array}{r}(3) \\
\text { TOTREV }\end{array}$ & $\begin{array}{r}(4) \\
\text { TOTREV }\end{array}$ & $\begin{array}{r}(5) \\
L A B S H A R\end{array}$ & $\begin{array}{r}(6) \\
L A B S H A R\end{array}$ & $\begin{array}{r}(7) \\
L A B S H A R\end{array}$ & $\begin{array}{r}(8) \\
\text { LABSHAR }\end{array}$ \\
\hline$L R G D P$ & $\begin{array}{r}19.31 \\
(6.31)\end{array}$ & $\begin{array}{l}14.78 \\
(4.47)\end{array}$ & $\begin{array}{r}15.29 \\
(4.20)\end{array}$ & $\begin{array}{r}15.01 \\
(4.42)\end{array}$ & $\begin{array}{r}6.49 \\
(2.01)\end{array}$ & $\begin{array}{r}2.35 \\
(0.78)\end{array}$ & $\begin{array}{r}10.00 \\
(2.61)\end{array}$ & $\begin{array}{r}3.44 \\
(1.27)\end{array}$ \\
\hline$\angle P O P$ & $\begin{array}{r}-2.06 \\
(-4.08)\end{array}$ & $\begin{array}{r}-3.22 \\
(-6.73)\end{array}$ & $\begin{array}{r}-6.05 \\
(-6.38)\end{array}$ & $\begin{array}{r}-3.14 \\
(-6.18)\end{array}$ & $\begin{array}{r}2.93 \\
(4.60)\end{array}$ & $\begin{array}{r}3.06 \\
(5.76)\end{array}$ & $\begin{array}{r}2.30 \\
(3.05)\end{array}$ & $\begin{array}{r}3.28 \\
(6.71)\end{array}$ \\
\hline POP65 & $\begin{array}{r}1.96 \\
(7.25)\end{array}$ & $\begin{array}{r}2.22 \\
(9.88)\end{array}$ & $\begin{array}{r}2.29 \\
(8.98)\end{array}$ & $\begin{array}{r}2.05 \\
(7.31)\end{array}$ & $\begin{array}{r}0.81 \\
(2.18)\end{array}$ & $\begin{array}{r}1.68 \\
(5.29)\end{array}$ & $\begin{array}{r}1.76 \\
(4.10)\end{array}$ & $\begin{array}{r}1.04 \\
(3.47)\end{array}$ \\
\hline$R A E$ & $\begin{array}{r}-0.41 \\
(-1.39)\end{array}$ & & & $\begin{array}{r}-0.37 \\
(-1.03)\end{array}$ & $\begin{array}{r}-2.07 \\
(-6.97)\end{array}$ & & & $\begin{array}{r}-1.32 \\
(-4.69)\end{array}$ \\
\hline NOM & & $\begin{array}{r}0.20 \\
(1.56)\end{array}$ & & $\begin{array}{r}0.25 \\
(1.65)\end{array}$ & & $\begin{array}{r}-0.48 \\
(-4.28)\end{array}$ & & $\begin{array}{r}-0.23 \\
(-1.69)\end{array}$ \\
\hline$N O P$ & & $\begin{array}{r}0.53 \\
(1.30)\end{array}$ & & $\begin{array}{r}0.22 \\
(0.43)\end{array}$ & & $\begin{array}{r}3.18 \\
(7.29)\end{array}$ & & $\begin{array}{r}2.20 \\
(4.55)\end{array}$ \\
\hline AVDURAT & & & $\begin{array}{r}-0.4 \\
(-0.89)\end{array}$ & $\begin{array}{r}-0.01 \\
(-0.28)\end{array}$ & & & $\begin{array}{r}0.01 \\
(0.14)\end{array}$ & $\begin{array}{r}0.02 \\
(0.55)\end{array}$ \\
\hline$I D E O L$ & $\begin{array}{r}-0.76 \\
(-0.91)\end{array}$ & & & & $\begin{array}{r}0.30 \\
(0.33)\end{array}$ & & & \\
\hline ELFRAC & & & $\begin{array}{r}-1.32 \\
(-0.52)\end{array}$ & & & & $\begin{array}{r}-4.95 \\
(-0.86)\end{array}$ & \\
\hline$R^{2}$ & 0.70 & 0.70 & 0.69 & 0.71 & 0.66 & 0.68 & 0.42 & 0.76 \\
\hline NOBS & 66 & 70 & 70 & 70 & 66 & 70 & 70 & 70 \\
\hline Robust to: & $L A M *$ & & & $L A M^{*}$ & $\begin{array}{l}L S Q \\
L A M\end{array}$ & $\begin{array}{l}\text { ENEP } \\
E N P P \\
E N G P\end{array}$ & & $\begin{array}{r}L A M \\
L S Q \\
E N E P \\
E N P P \\
E N G P\end{array}$ \\
\hline Fixed effects: & & & AVDURAT & AVDURAT & $R A E(+)$ & & & \\
\hline Random effects: & & & AVDURAT & AVDURAT & $\begin{array}{l}R A E \\
L A M\end{array}$ & $\begin{array}{r}N O P \\
E N P P \\
E N G P\end{array}$ & & $\begin{array}{c}R A E \\
L A M \\
L S Q \\
N O P \\
E N E P \\
E N P P \\
E N G P\end{array}$ \\
\hline
\end{tabular}

Notes: All equations include time dummies. Robust standard errors. $t$-statistics in parentheses.

* Significant if included instead of standard variable. 
Table 3b. Revenue and Political Variables

\begin{tabular}{|c|c|c|c|c|c|c|c|c|}
\hline Dependent Variable & $\begin{array}{r}\text { (1) } \\
\text { CAPSHAR }\end{array}$ & $\begin{array}{r}(2) \\
\text { CAPSHAR }\end{array}$ & $\begin{array}{r}(3) \\
\text { CAPSHAR }\end{array}$ & $\begin{array}{r}(4) \\
\text { CAPSHAR }\end{array}$ & $\begin{array}{r}(5) \\
\text { CONSHAR }\end{array}$ & $\begin{array}{r}(6) \\
\text { CONSHAR }\end{array}$ & $\begin{array}{r}(7) \\
\text { CONSHAR }\end{array}$ & $\begin{array}{r}(8) \\
\text { CONSHAR }\end{array}$ \\
\hline$L R G D P$ & $\begin{array}{r}0.25 \\
(0.16)\end{array}$ & $\begin{array}{r}1.44 \\
(0.87)\end{array}$ & $\begin{array}{r}0.51 \\
(0.31)\end{array}$ & $\begin{array}{r}1.09 \\
(0.69)\end{array}$ & $\begin{array}{r}-6.68 \\
(-2.00)\end{array}$ & $\begin{array}{r}-4.16 \\
(-1.40)\end{array}$ & $\begin{array}{r}-8.07 \\
(-2.11)\end{array}$ & $\begin{array}{r}-4.96 \\
(-1.78)\end{array}$ \\
\hline$\angle P O P$ & $\begin{array}{r}-0.14 \\
(-0.35)\end{array}$ & $\begin{array}{r}0.08 \\
(0.27)\end{array}$ & $\begin{array}{r}0.24 \\
(0.81)\end{array}$ & $\begin{array}{r}0.02 \\
(0.05)\end{array}$ & $\begin{array}{r}-2.08 \\
(-4.09)\end{array}$ & $\begin{array}{r}-1.90 \\
(-5.11)\end{array}$ & $\begin{array}{r}-1.48 \\
(-3.68)\end{array}$ & $\begin{array}{r}-2.04 \\
(-5.28)\end{array}$ \\
\hline POP65 & $\begin{array}{r}-0.15 \\
(-0.68)\end{array}$ & $\begin{array}{r}-0.38 \\
(-2.10)\end{array}$ & $\begin{array}{r}-0.45 \\
(-2.76)\end{array}$ & $\begin{array}{r}-0.18 \\
(-0.94)\end{array}$ & $\begin{array}{r}-0.24 \\
(-0.89)\end{array}$ & $\begin{array}{r}-0.75 \\
(-3.06)\end{array}$ & $\begin{array}{r}-0.81 \\
(-2.83)\end{array}$ & $\begin{array}{r}-0.30 \\
(-1.22)\end{array}$ \\
\hline$R A E$ & $\begin{array}{r}0.47 \\
(3.07)\end{array}$ & & & $\begin{array}{r}0.42 \\
(2.59)\end{array}$ & $\begin{array}{r}1.34 \\
(4.03)\end{array}$ & & & $\begin{array}{r}0.93 \\
(3.10)\end{array}$ \\
\hline$N O M$ & & $\begin{array}{r}0.02 \\
(0.37)\end{array}$ & & $\begin{array}{r}-0.06 \\
(-0.76)\end{array}$ & & $\begin{array}{r}0.23 \\
(2.28)\end{array}$ & & $\begin{array}{r}0.05 \\
(0.66)\end{array}$ \\
\hline NOP & & $\begin{array}{r}-0.58 \\
(-2.40)\end{array}$ & & $\begin{array}{r}-0.28 \\
(-1.07)\end{array}$ & & $\begin{array}{r}-1.66 \\
(-5.45)\end{array}$ & & $\begin{array}{r}-1.00 \\
(-2.88)\end{array}$ \\
\hline AVDURAT & & & $\begin{array}{r}0.01 \\
(0.21)\end{array}$ & $\begin{array}{r}-0.01 \\
(-0.35)\end{array}$ & & & $\begin{array}{r}-0.01 \\
(-0.25)\end{array}$ & $\begin{array}{r}-0.03 \\
(-0.70)\end{array}$ \\
\hline$I D E O L$ & $\begin{array}{r}-0.17 \\
(-0.39)\end{array}$ & & & & $\begin{array}{r}0.78 \\
(0.83)\end{array}$ & & & \\
\hline ELFRAC & & & $\begin{array}{r}-0.16 \\
(-0.13)\end{array}$ & & & & $\begin{array}{r}2.30 \\
(0.63)\end{array}$ & \\
\hline$R^{2}$ & 0.28 & 0.25 & 0.19 & 0.31 & 0.52 & 0.48 & 0.33 & 0.57 \\
\hline NOBS & 66 & 70 & 70 & 70 & 66 & 70 & 70 & 70 \\
\hline Robust to: & $\begin{array}{r}L A M \\
L S Q\end{array}$ & $\begin{array}{l}E N E P \\
E N P P \\
E N G P\end{array}$ & & & $\begin{array}{l}L S Q \\
L A M\end{array}$ & $\begin{array}{l}\text { ENEP } \\
E N P P \\
E N G P\end{array}$ & & $\begin{array}{r}L S Q \\
L A M \\
E N E P \\
E N P P \\
E N G P\end{array}$ \\
\hline Fixed effects: & & & & & $R A E(-)$ & $\begin{array}{l}E N E P(+) \\
E N P P(+)\end{array}$ & & $\begin{array}{c}R A E(-) \\
E N E P(+) \\
E N P P(+)\end{array}$ \\
\hline Random effects: & & & & & $L A M$ & & & $L A M$ \\
\hline
\end{tabular}

Notes: All equations include time dummies. Robust standard errors. $t$-statistics in parentheses. 
for the cabinet size (NOM) works in the opposite direction, with a larger cabinet associated with a higher consumption tax share and a lower labor tax share.

The revenue results-particularly reflecting the effects of the electoral system and fragmentation -are pretty robust, at least for labor and consumption taxation. They work for all definitions of proportionality and fragmentation, and the results remain strong when the key variables are included together in estimating a single equation. Further, the results largely hold up under random effects estimation, especially those pertaining to the labor tax share. In terms of fixed effects, however, proportionality seems to work in the opposite direction, suggesting that as countries become ex post more proportional over time, they move towards lower labor shares and higher consumption shares. Furthermore, higher within-country effective number of parties actually leads to a higher consumption tax share. ${ }^{11}$ Government instability seems to have no effect on tax choice, a result that diverges from the expenditure findings. Similarly, neither ideology nor ethnolinguistic fractionalization appear to impact the choice of tax system.

\section{Summary of results}

Table 4 provides a summary of the qualitative effects of political variables on fiscal outcomes. The results indicate:

- More proportional electoral systems tend to be associated with higher total expenditure, higher transfers, lower government wage consumption, a lower overall balance, a higher relative tax burden on labor, and lower relative tax burdens on capital and consumption. The results for transfers and government wages are consistent with the hypothesis that proportional electoral systems lead to more transfers, while majoritarian systems favor public goods.

- $\quad$ The size of coalition, plus some other indices of fragmentation, is associated with higher total expenditure, higher transfers, a lower overall balance, a higher relative tax burden on labor, and lower relative tax burdens on capital and consumption.

- A large cabinet size is associated with higher total expenditure, higher wage government consumption, a lower relative tax burden on labor, and a higher relative tax burden on consumption.

- Short-lived governments are associated with higher total expenditure, higher transfers, higher wage government consumption, and a lower overall balance. Within countries over time, longer-lived governments are associated with lower total expenditure, transfers, and revenue.

- A more fractionalized country along ethnic and linguistic grounds is associated with lower transfers and higher wage government consumption.

- $\quad$ There is no effect of government ideology on fiscal policy.

\footnotetext{
${ }^{11}$ This seems to be the counterpart to the within-country reduction in transfers associated with a high effective number of parties. The same caveat applies, given the limited time variation of these variables.
} 
Table 4. Summary of Basic Results 1/

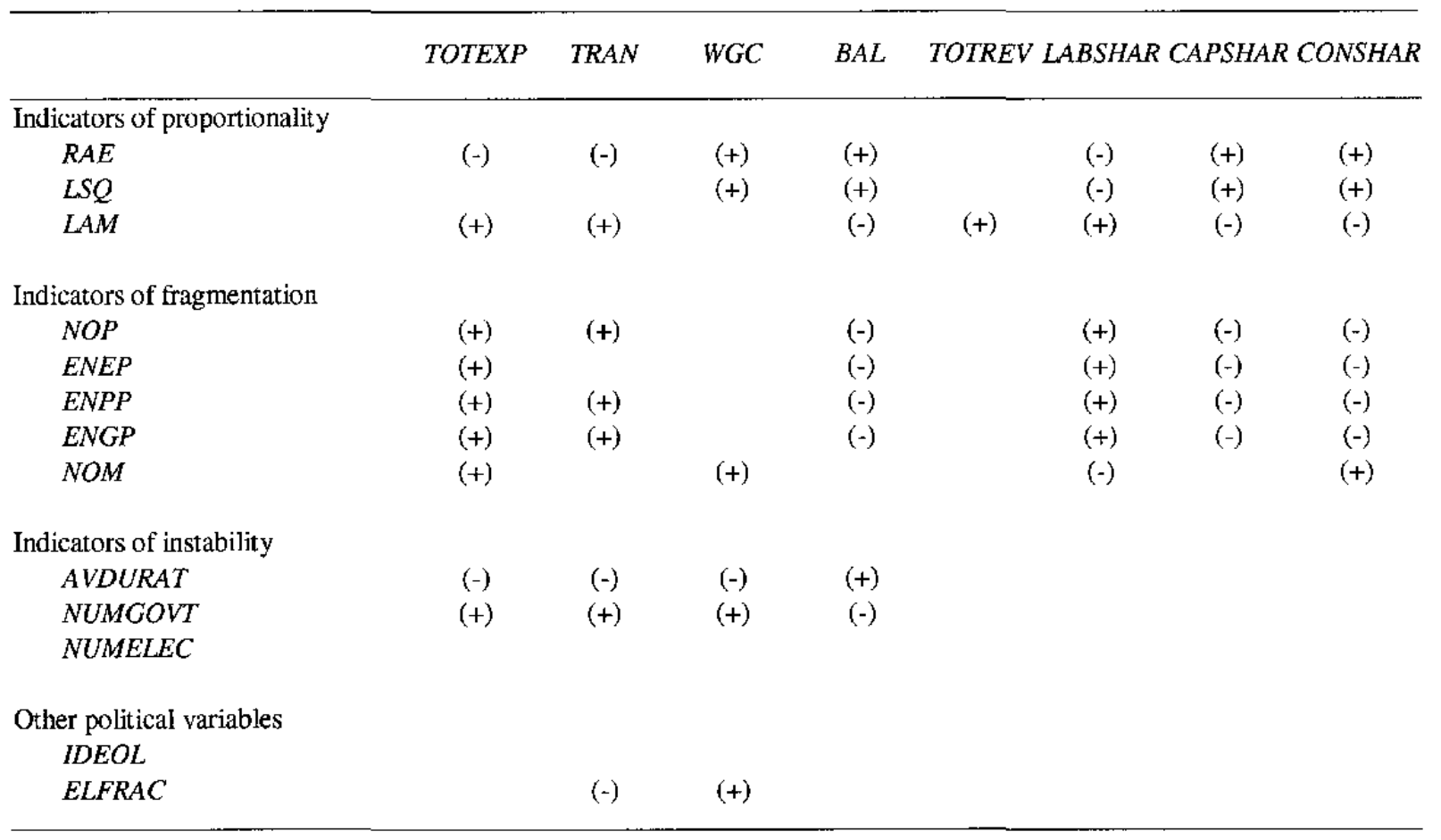

1/ Based on OLS. equations of Tables $2 a, 2 b, 3 a$, and $3 b$.

Many of these results confirm other findings in the literature, such as the association between some kinds of political institutions - elections conducted by proportional representation, governments dominated by unstable coalitions-and certain outcomes, such as lower overall balances and larger governments. There is clear evidence that all three types of political variables affect outcomes. Some of the results are clearly more original, including the different conclusions for government wages and transfers, and for labor and consumption taxation. In terms of expenditure, the electoral system affects transfers and government wages in opposing ways. While fragmentation matters for both, it is coalition size for transfers and cabinet size for government wages. The results on the revenue side, focusing on the choice between labor and consumption taxation, are also fairly new. They suggest that proportional electoral systems, and countries with coalitions, tend to choose labor taxes, while countries with large cabinets opt for consumption taxes.

\section{B. Evidence on Adjustment}

\section{Methodology}

As noted at the outset, the chosen period is one of significant fiscal adjustment. Responding to fiscal deterioration in the $1980 \mathrm{~s}$, some countries began to adjust in the late $1980 \mathrm{~s}$. A growth slowdown in the early 1990s coincided with some slippage, but adjustment roared ahead in the 
latter half of the decade, with particular emphasis on controlling expenditure. Further, as discussed already, this adjustment was complemented by deep-rooted institutional reforms.

This section is concerned with how political variables affect the degree of fiscal adjustment. Accordingly, the dependent variable in the regression analysis becomes the difference between the five-year average value of a fiscal variable in period $t$, minus the five-year average value of the same variable in period ( $t-1)$. Thus what matters is the amount of adjustment undertaken. This definition picks up the three periods of interest: the late 1980s, the early 1990s, and the late 1990s.

A natural question to ask is whether the adjustment is more aggressive in countries with adverse political circumstances. If the ultimate goal is some form of convergence in fiscal policy, which is what Maastricht aspires to, then the largest adjustment should be seen among countries with poorer fiscal outturns. Thus if a component of fiscal policy is influenced by political factors, then the success of the adjustment can be measured by whether or not countries with these same political factors have larger adjustments. The new institutional framework, including fiscal rules, may well aid these countries in the process of adjustment. With taxation it is more complicated: if the goal is to reduce the deficit, then raising taxes is a response, but if governments are more concerned about reducing the size of government or curbing the disincentive effects of taxation, then cutting taxes may be the chosen strategy. In general, even if there is a certain degree of convergence in the overall balance, it does not necessarily follow that countries will make the same compositional choices.

Two important control variables are included in each regression: the debt-GDP ratio as measured at the beginning of the period $(D E B T O)$ and the average annual real growth rate within the period (GROWTH). The debt variable captures the urgency of adjustment; countries with higher debt will be more inclined to adjust. The growth variable captures the idea that adjustment is made easier by favorable circumstances, typified by higher growth rates in a country. ${ }^{12}$

There is no clear link between political factors and adjustment. The hypothesis being tested is that the same variables which led to unfavorable outcomes in the first place should also prompt more adjustment. Controlling for growth and initial debt, there is virtually no effect of fiscal variables on adjustment. Indeed, even absent such variables, the impact of these political variables is minimal. ${ }^{13}$ The control variables are important, however. In particular, initial debt is associated with greater expenditure adjustment-especially transfers and wage government consumption - and a higher fiscal balance; the result is weaker for revenue, suggesting that higher debt has not prompted revenue-based adjustment. Adjustment is also facilitated in high growth periods, especially on the expenditure side. This could capture either conscious policy decisions or the operation of automatic stabilizers. On the revenue side, average tax rates tend to fall in periods of high growth. This suggests that governments have tended to take advantage of

\footnotetext{
${ }^{12}$ Of course, causality may be reversed in that adjustment may lead to higher growth as in Alesina and Perotti (1997b).

${ }^{13}$ These results are not reported.
} 
good times during this period to reduce taxes, thus neutralizing the effects of automatic stabilizers. Growth, therefore, has no significant influence on the overall balance.

The poor performance of political variables in explaining adjustment can be accorded a number of interpretations. First, the inclusion of the debt variable takes care of initial conditions, so that political variables have little left to explain. However, even if DEBTO was not included in these equations, the political variables would have minimal predictive power. Another interpretation is that all countries adjusted during this period, not merely those with the kinds of institutions that favor big government and profligate fiscal policy. Certainly, while there is no fiscal convergence, there is also no evidence that adjustment is being hindered by the prevailing institutions in this group of countries.

Another possibility is that the story told by the regressions is not so clear-cut, and that the interrelationship between growth, initial debt, and the political variables is a complex one. Overcoming political constraints is difficult, and may require favorable conditions. It may only be possible to overcome such constraints when conditions are favorable (high growth) or when circumstances are dire (high initial debt). Under this scenario, the political variables would exert a different influence depending on whether growth, or the initial debt level, was high. In terms of the econometrics, this means looking for a non-linear relationship in the data, through interactive terms.

\section{Adjustment, politics, and growth}

Table 5 presents some of the key results from the interaction between growth and the political variables. The idea is to test the hypothesis that the degree of adjustment in countries with institutions associated with fiscal profligacy will be larger when conditions are more favorable. In other words, if governments with politically induced high expenditure, revenue, or deficits need to adjust more, they will find it easier to overcome vested interests in good times.

The results of Table 5 are broadly favorable to this hypothesis. Looking first at total expenditure, the evidence suggests that while the coefficient on growth remains negative and significant, that on the interaction between growth and disproportionality $(L S Q)$ is positive and significant (at least at the 10 percent level). One interpretation is that while growth is good for expenditure-based adjustment, it is less so under nonproportional electoral systems. In other words, with high growth, the expenditure adjustment is greater under more proportional electoral systems. This result is robust to the district magnitude variable ( $L A M)$, but not $R A E$. The same story emerges from different political variables. It holds for the parliamentary fragmentation induced by a large number of parties $(E N P P)$. Column 2 shows that while growth and more government stability both contribute to expenditure restraint, the interactive term is positive, signaling that more short-lived governments act more to control expenditure when growth is high. Thus the effects of instability can therefore be overcome in good times. ${ }^{14}$

\footnotetext{
${ }^{14}$ Of course, an alternative hypothesis here is that the causality is reversed, and that the fiscal adjustment is leading to short tenure in office.
} 
Table 5. Fiscal Adjustment, Growth, and Political Variables

\begin{tabular}{|c|c|c|c|c|c|c|c|c|}
\hline Dependent Variable & $\begin{array}{r}(1) \\
\text { DTOTEXP }\end{array}$ & $\begin{array}{r}(2) \\
\text { DTOTEXP }\end{array}$ & $\begin{array}{r}\text { (3) } \\
\text { DTRAN }\end{array}$ & $\begin{array}{r}(4) \\
\text { DTRAN }\end{array}$ & $\begin{array}{r}(5) \\
D W G C\end{array}$ & $\begin{array}{r}(6) \\
\text { DTOTREV }\end{array}$ & $\begin{array}{r}(7) \\
\text { DCONSHAR }\end{array}$ & $\begin{array}{r}(8) \\
D B A L\end{array}$ \\
\hline DEBTO & $\begin{array}{r}-0.04 \\
(-3.28)\end{array}$ & $\begin{array}{r}-0.05 \\
(-3.71)\end{array}$ & $\begin{array}{r}-0.02 \\
(-2.33)\end{array}$ & $\begin{array}{r}-0.02 \\
(-2.53)\end{array}$ & $\begin{array}{r}-0.01 \\
(-1.99)\end{array}$ & $\begin{array}{r}0.03 \\
(2.27)\end{array}$ & $\begin{array}{l}-0.001 \\
(-0.06)\end{array}$ & $\begin{array}{r}0.06 \\
(5.58)\end{array}$ \\
\hline GROWTH & $\begin{array}{r}-1.84 \\
(-3.57)\end{array}$ & $\begin{array}{r}0.42 \\
(1.15)\end{array}$ & $\begin{array}{r}-0.82 \\
(-2.62)\end{array}$ & $\begin{array}{r}0.22 \\
(0.99)\end{array}$ & $\begin{array}{r}0.34 \\
(1.34)\end{array}$ & $\begin{array}{r}1.10 \\
(1.30)\end{array}$ & $\begin{array}{r}0.53 \\
(1.63)\end{array}$ & $\begin{array}{r}-0.53 \\
(-1.49)\end{array}$ \\
\hline$L S Q$ & $\begin{array}{r}-0.30 \\
(-1.30)\end{array}$ & & $\begin{array}{r}-0.14 \\
(-1.33)\end{array}$ & & & & $\begin{array}{r}0.22 \\
(1.67)\end{array}$ & \\
\hline$L S Q * G R O W T H$ & $\begin{array}{r}0.12 \\
(1.78)\end{array}$ & & $\begin{array}{r}0.06 \\
(1.84)\end{array}$ & & & & $\begin{array}{r}-0.08 \\
(-1.70)\end{array}$ & \\
\hline NUMGOVT & & $\begin{array}{r}1.72 \\
(3.35)\end{array}$ & & $\begin{array}{r}0.74 \\
(2.35)\end{array}$ & & & & $\begin{array}{r}-0.98 \\
(-1.90)\end{array}$ \\
\hline NUMGOVT*GROWTH & -0.51 & $(-4.24)$ & -0.22 & $(-2.53)$ & & & & $\begin{array}{r}0.31 \\
(2.61)\end{array}$ \\
\hline ENEP & & & & & $\begin{array}{r}0.34 \\
(2.02)\end{array}$ & $\begin{array}{r}0.57 \\
(1.00)\end{array}$ & & \\
\hline$E N E P * G R O W T H$ & & & & & $\begin{array}{r}-0.13 \\
(-2.19)\end{array}$ & $\begin{array}{r}-0.45 \\
(-2.15)\end{array}$ & & \\
\hline IDEOL & & & & & & $\begin{array}{r}0.88 \\
(2.13)\end{array}$ & $\begin{array}{r}-0.35 \\
(-0.60)\end{array}$ & $\begin{array}{r}0.07 \\
(0.12)\end{array}$ \\
\hline $\begin{array}{l}R^{2} \\
\text { NOBS }\end{array}$ & $\begin{array}{r}0.56 \\
49\end{array}$ & $\begin{array}{r}0.60 \\
49\end{array}$ & $\begin{array}{r}0.55 \\
49\end{array}$ & $\begin{array}{r}0.57 \\
49\end{array}$ & $\begin{array}{r}0.29 \\
54\end{array}$ & $\begin{array}{r}0.51 \\
46\end{array}$ & $\begin{array}{r}0.09 \\
46\end{array}$ & $\begin{array}{r}0.63 \\
47\end{array}$ \\
\hline Robust to: & $\begin{array}{r}L A M \\
E N P P\end{array}$ & AVDURAT & $\begin{array}{r}L A M \\
E N E P \\
E N P P\end{array}$ & & $\begin{array}{r}N O P \\
E N P P \\
E N G P\end{array}$ & $\begin{array}{r}L A M \\
E N P P\end{array}$ & $\begin{array}{l}R A E \\
L A M\end{array}$ & \\
\hline Fixed effects: & & & $\begin{array}{r}L A M \\
N O P \\
E N E P \\
E N P P\end{array}$ & & & $\begin{array}{l}\text { ENEP } \\
\text { ENPP }\end{array}$ & & \\
\hline Random effects: & $\begin{array}{r}L S Q \\
N O P \\
E N P P \\
E N G P\end{array}$ & NUMGOVT & $\begin{array}{c}L S Q \\
L A M \\
N O P \\
E N E P \\
E N P P \\
E N G P\end{array}$ & MGOVT & $\begin{array}{r}N O P \\
E N G P\end{array}$ & $\begin{array}{r}L A M \\
E N E P \\
E N P P\end{array}$ & $R A E$ & MGOVT \\
\hline
\end{tabular}

Notes: All equations include time dummies. Robust standard errors. $t$-statistics in parentheses. 
A similar story holds for transfers. Column 3 shows that while favorable economic conditions facilitate curbing the growth of transfers, this is more pronounced in proportional electoral systems reflecting the need for greater adjustment in these cases. Furthermore, the result holds for more fragmented electorates and parliaments suggesting that the effects of such fragmentation can be overcome in good times to cut the growth of transfers. The constraints imposed by government instability can also be overcome in good times (column 4). The results are weaker for the other components of expenditure. Column 5 does show, however, that fragmented legislatures and governments-measured by the effective number of parties in parliament and government, as well as the raw number of parties in coalition--are associated with greater restraint as of the government wage bill in high growth situations. In summary, politicians are willing to overcome political constraints to tackle the thorny issues of transfers and government wages - which according to Alesina and Perotti (1997b) are required for durable adjustments-but only when circumstances are favorable. The key results, especially for transfers, are robust to estimation by fixed and random effects methods.

There is also evidence of non-linear effects on the revenue side. More fragmented countries (higher ENEP or ENPP) take advantage of high growth to cut taxes, or at least do not resort to higher taxes in the adjustment process to the same extent (column 6). There is also some evidence that the negative effects of proportionality on taxation can be mitigated in periods of high growth. This result is robust to both fixed and random effects estimation. In high growth periods, fragmented governments, and those with proportional electoral systems, try to counteract politically induced big government by restraining both expenditure and taxation. ${ }^{15}$ There is no evidence that taxes are raised to deal with a deficit bias. Another result to emerge on the revenue side is that, in high growth situations, more proportional governments attempt to shift taxation towards a consumption base, thus reversing the observed pattern in the previous section (column 7); again, this is robust to fixed and random effects estimation.

Table 5 also looks at the relationship between the change in the overall balance, growth, and political variables (column 8). However, the only political variable of relevance here is political instability (more specifically, $N U M G O V T$ ). While a large number of governments within the period in question leads to a lower adjustment in the fiscal balance, this effect is mitigated in a high growth environment, where the effects of instability can be overcome, and the fiscal position improved. The relatively weaker result for the overall balance suggests that what motivates government is not so much the deficit target itself, but controlling the size of government in terms of both expenditure and revenue.

\section{Adjustment, politics, and initial conditions}

Besides growth, it is also possible that initial conditions matter, as high debt provides an added incentive to overcome political roadblocks to adjustment. Table 6 reports some of the results obtained by interacting initial debt with some of the political variables. On the expenditure side, there is evidence of an effect on transfers, but nothing else (columns 1 and 2). Using $L A M$ as the

\footnotetext{
${ }^{15}$ Talvi and Vegh (2000) argue that governments choose lower taxes in good times to counteract the political pressures to increase spending.
} 
Table 6. Fiscal Adjustment, Initial Debt, and Political Variables

\begin{tabular}{|c|c|c|c|c|c|c|}
\hline & (1) & (2) & (3) & (4) & (5) & (6) \\
\hline Dependent Variable & DTRAN & DTRAN & TOTREV & BSHAR & DCONSHAR & DCONSHAR \\
\hline$D E B T O$ & $\begin{array}{r}0.01 \\
(0.39)\end{array}$ & $\begin{array}{r}0.02 \\
(1.00)\end{array}$ & $\begin{array}{r}0.08 \\
(2.74)\end{array}$ & $\begin{array}{r}0.03 \\
(1.70)\end{array}$ & $\begin{array}{r}-0.05 \\
(-2.44)\end{array}$ & $\begin{array}{r}-0.08 \\
(-3.13)\end{array}$ \\
\hline GROWTH & $\begin{array}{r}-0.49 \\
(-2.71)\end{array}$ & $\begin{array}{r}-0.44 \\
(-2.89)\end{array}$ & $\begin{array}{r}-0.64 \\
(-3.88)\end{array}$ & $\begin{array}{r}-0.03 \\
(-0.15)\end{array}$ & $\begin{array}{r}0.14 \\
(0.85)\end{array}$ & $\begin{array}{r}0.00 \\
(0.001)\end{array}$ \\
\hline$L A M$ & $\begin{array}{r}0.72 \\
(1.63)\end{array}$ & & & $\begin{array}{r}1.54 \\
(2.58)\end{array}$ & $\begin{array}{r}-1.49 \\
(-2.92)\end{array}$ & \\
\hline$L A M^{*} D E B T O$ & $\begin{array}{r}-0.01 \\
(-2.09)\end{array}$ & & & $\begin{array}{r}-0.02 \\
(-2.95)\end{array}$ & $\begin{array}{r}0.03 \\
(3.30)\end{array}$ & \\
\hline NOP & & $\begin{array}{r}1.10 \\
(2.31)\end{array}$ & $\begin{array}{r}1.55 \\
(2.34)\end{array}$ & & & $\begin{array}{r}-2.22 \\
(-4.59)\end{array}$ \\
\hline$N O P^{*} D E B T O$ & & $\begin{array}{r}-0.01 \\
(-2.46)\end{array}$ & $\begin{array}{r}-0.02 \\
(-2.62)\end{array}$ & & & $\begin{array}{r}0.03 \\
(3.92)\end{array}$ \\
\hline IDEOL & & & $\begin{array}{r}1.11 \\
(2.47)\end{array}$ & $\begin{array}{r}-0.47 \\
(-0.91)\end{array}$ & $\begin{array}{r}-0.53 \\
(-1.02)\end{array}$ & $\begin{array}{r}-0.84 \\
(-1.75)\end{array}$ \\
\hline $\begin{array}{l}R^{2} \\
\text { NOBS }\end{array}$ & $\begin{array}{r}0.58 \\
47\end{array}$ & $\begin{array}{r}0.60 \\
49\end{array}$ & $\begin{array}{r}0.47 \\
46\end{array}$ & $\begin{array}{r}0.30 \\
44\end{array}$ & $\begin{array}{r}0.25 \\
44\end{array}$ & $\begin{array}{r}0.33 \\
46\end{array}$ \\
\hline Robust to: & & $E N G P$ & $E N G P$ & $\begin{array}{l}R A E \\
L S Q\end{array}$ & $\begin{array}{l}R A E \\
L S Q\end{array}$ & $\begin{array}{l}\text { ENEP } \\
E N P P \\
E N G P\end{array}$ \\
\hline Fixed effects: & $L A M$ & NOP & $\begin{array}{r}L A M \\
N O P \\
E N G P\end{array}$ & $L S Q$ & $L A M$ & $\begin{array}{r}\text { NOP } \\
\text { ENEP } \\
\text { ENPP } \\
\text { ENGP }\end{array}$ \\
\hline Random effects: & $\begin{array}{r}L A M \\
L S Q\end{array}$ & $\begin{array}{r}N O P \\
E N E P \\
E N P P \\
E N G P\end{array}$ & $N O P$ & $\begin{array}{r}L A M \\
L S Q \\
R A E\end{array}$ & $\begin{array}{r}L A M \\
R A E\end{array}$ & $\begin{array}{r}N O P \\
E N E P \\
E N P P \\
E N G P\end{array}$ \\
\hline
\end{tabular}

Notes: All equations include time dummies. Robust standard errors, $t$-statistics in parentheses. 
measure of proportionality, the coefficient on its interaction with initial debt is negative and significant, implying that the tendency towards higher transfers in countries with proportional electoral systems is mitigated in high debt circumstances. The coefficient on $L A M$ itself is positive, pointing towards the continued effect of proportionality on transfers in the absence of high debt. A similar result, however, can be seen from column 2 which deals with the number of coalition parties (NOP). In this case, while large coalitions favor growth in transfers, this is counteracted in circumstances of high debt, when transfers fall. Political constraints to curbing the growth of transfers are overcome when initial conditions are unfavorable. These results are robust to both fixed and random effects estimation.

The remainder of Table 6 deals with revenue. Column 3 focuses on total revenue. The coefficient on initial debt itself is positive and significant, suggesting that revenue-based adjustment can under certain circumstances be a response to high debt. This equation also includes the number of coalition parties $(N O P)$. Coalition size tends to lead to higher taxes; however, this tendency is mitigated in high debt circumstances. Initial debt prompts lower taxes when the government is fragmented. What this says is that the effects of high debt on revenue go beyond a mere need to reduce the deficit. Again, this result is robust to both fixed and random effects estimation; it even works for proportionality $(L A M)$ with fixed effects.

Initial debt also has implications for the choice between labor and consumption taxes. Recall that certain political systems - specifically, those with proportional electoral systems and fragmented governments-prefer labor taxes to consumption taxes. There is some evidence that when initial debt is high, these governments are prompted to reverse this process, and move from labor to consumption taxes. Column 4 shows that, although a more proportional electoral system $(L A M)$ induces a larger increase in the labor tax share, this is reversed when initial debt is high. The exact opposite is true for consumption taxes: proportionality reduces their share in total revenue, except when debt is high, when the share increases (column 5). Once again, these results hold for fixed and random effects estimation. The hypothesis is also valid for large coalitions and other indicators of fragmentation, at least the consumption tax share (column 6).

\section{Summary of results}

- The effect of political variables on fiscal adjustment depends on the rate of growth and the size of initial debt.

- During high-growth periods, there is a stronger attempt to undertake an expenditurebased adjustment (especially in transfers but also in wage government consumption) in countries with proportional electoral systems, fragmented governments and legislatures, and short-lived governments. Fragmented governments are also more likely to reduce the tax burden during high growth periods.

- If initial debt is high, countries are more likely to curb the growth of transfers in regimes characterized by proportional electoral systems or fragmented governments.

- If initial debt is high, countries are more likely to shift the tax burden from labor to consumption in regimes characterized by proportional electoral systems and fragmented governments. 


\section{Conclusion}

The first part of this paper presents a general overview of the literature, both theoretical and empirical, relating to the effect of political factors on fiscal policy, especially in industrial countries. This literature, much of it recent, covers the effects of politics and institutions on the overall deficit as well as on the size and composition of government spending and concentrates on the different manifestations of the kind of distributional conflict inherent in fiscal policy.

Following this, the second part of the paper launches a comprehensive investigation into the effects of political variables on fiscal policy, using panel data for 19 industrial countries. It is clear that politics matters in determining the size and composition of expenditure and revenue, as well as the overall balance. One pattern that emerges is that certain political factors--such as an electoral system emphasizing proportionality, a fragmented parliament or government, or short-lived governments-give rise to a confluence of higher transfers, bigger government, and a revenue system emphasizing labor taxes over consumption taxes.

At the same time, there has been a concerted effort at fiscal adjustment, which became especially pronounced in the late 1990s. Partly to overcome the negative effects of politics, countries adopted an array of institutional changes including better budget processes and fiscal rules to reduce the scope for political discretion. The empirical section of this paper also shows that countries did, indeed, make an effort to reverse the observed politically induced pattern of fiscal policy over this period, but only when conditions were favorable or when initial debt was sufficiently high. In particular, countries afflicted by the political bias noted above were more likely to try and reverse the pattern by curbing the growth of transfers and switching from labor taxes to consumption taxes when growth or initial debt was high enough. This does not bode well for the quality of adjustment in low-growth periods. But the newly instituted fiscal policy frameworks may prevent the emergence of politically motivated fiscal policy in the future. 


\section{Data Description}

\section{Economic Variables}

TOTEXP: Total government expenditure, divided by GDP. Source: OECD

TRAN: Social security benefits paid by the government plus other current transfers paid by the government, divided by GDP. Source: OECD

WGC: Government final wage consumption expenditure, divided by GDP. Source: OECD

$\boldsymbol{B A} L$ : General government fiscal balance, divided by GDP. Source: OECD

TOTREV: Total government current receipts, divided by GDP. Source: OECD

LABSHAR: Direct taxes on household plus social security contributions received by the government, divided by total government current receipts. Source: OECD

CAPSHAR: Direct taxes on business, divided by total government current receipts. Source: OECD

CONSHAR: Indirect taxes, divided by total government current receipts. Source: OECD

LRGDP: Log of real GDP per capita, PPP basis. Source: OECD

LPOP: Log of population. Source: OECD

POP65: Percent of population aged 65 and over. Source: OECD

DEBT0: General government gross debt at beginning of 5-year period, divided by GDP. Source: OECD

GROWTH: Average annual real GDP growth rate within a 5-year period. Source: OECD

Any variable prefixed by D means the value of the variable in the current 5-year period minus the value of the same variable in the previous 5-year period.

\section{Political Variables}

$L S Q$ : Least-squares method of calculating the degree of disproportionality based on Gallagher (1991), defined as the square root of the sum of squares of the deviations between vote and seat percentages.

Formally, $L S Q=\sqrt{\frac{1}{2} \sum_{p=1}^{P}\left(v_{p_{-}} s_{p}\right)^{2}}$, where $\mathrm{p}$ is a party index, $\mathrm{s}_{\mathrm{p}}$ is the share of seats obtained by party $\mathrm{p}$ in parliament, and $\mathrm{v}_{\mathrm{p}}$ is the share of votes won by party $\mathrm{p}$ in the election. Source: Lijphart (1994) through 1990, Milesi-Ferretti, Perotti and Rostagno (2001) through 1995, and author's calculations through 1999.

$\boldsymbol{R A E}$ : Average deviation method of calculating the degree of disproportionality based on Rae (1967), defined as the average of the deviations (in absolute values) of the shares of electoral votes of each party from its share of seats in parliament. 
Formally, Rae $=\sum_{p=1}^{P}\left|v_{p}-s_{p}\right|$, where $\mathrm{p}$ is a party index, $\mathrm{s}_{\mathrm{p}}$ is the share of seats obtained by party $\mathrm{p}$ in parliament, and $\mathrm{v}_{\mathrm{p}}$ is the share of votes won by party $\mathrm{p}$ in the election. Source: Lijphart (1994) through 1990, Milesi-Ferretti, Perotti and Rostagno (2001) through 1995, and author's calculations through 1999.

$L A M: \log$ of average district magnitude, whereby the average district magnitude is the weighted average of the average district size of the two tiers of an electoral system (if there are two tiers), with weights equal to the proportion of representatives elected in each tier.

Formally, $A M=\frac{\left(d_{1} S_{1}+d_{2} S_{2}\right)}{S_{\text {tot }}}$, where $\mathrm{d}_{1}$ and $\mathrm{d}_{2}$ are the average district sizes of each tier (the total number of seats divided by the number of districts in each tier), while $S_{1}$ and $S_{2}$ are the number of representatives elected at each tier and $S_{\text {tot }}$ is the total number of elected representatives. Source: Milesi-Ferretti, Perotti and Rostagno (2001).

ENEP: Effective number of elective parties, defined as the inverse of the sum of squared vote shares of each party contesting the election.

Formally, ENEP $=\frac{1}{\sum_{p=1}^{P} y_{p}^{2}}$, where $\mathrm{p}$ is a party index and $\mathrm{v}_{\mathrm{p}}$ is the share of votes won by

party p in the election. Source: Lijphart (1994) through 1990, Milesi-Ferretti, Perotti and Rostagno (2001) through 1995, and author's calculations through 1999.

ENPP: Effective number of parliamentary parties, defined as the inverse of the sum of squared seat shares of each party in parliament.

Formally, $E N E P=\frac{1}{\sum_{p=1}^{P} s_{p}^{2}}$, where $\mathrm{p}$ is a party index and $\mathrm{s}_{\mathrm{p}}$ is the share of votes won by

party p in the election. Source: Lijphart (1994) through 1990, Milesi-Ferretti, Perotti and Rostagno (2001) through 1995, and author's calculations through 1999.

ENGP: Effective number of government parties, defined as the inverse of the sum of squared seat shares of each party in government.

Formally, $E N E P=\frac{1}{\sum_{p=1}^{P} g_{p}^{2}}$, where $\mathrm{p}$ is a party index and $\mathrm{g}_{\mathrm{p}}$ is the share of votes won by party $\mathrm{p}$ in the election. Source: Author's calculations based on Woldendorp, Keman, and Budge (2000).

NOP: Number of parties in government. Source: Woldendorp, Keman, and Budge (2000).

NOM: Number of ministers in government. Source: Woldendorp, Keman, and Budge (2000).

NUMGOVT: Average number of governments within the particular 5-year period in a given country. Source: Woldendorp, Keman, and Budge (2000). 
NUMELEC: Average number of elections within the particular 5-year period in a given country. Source: Woldendorp, Keman, and Budge (2000).

AVDURAT: Average duration, in months, of all governments within the particular 5-year period in a given country. Source: Woldendorp, Keman, and Budge (2000).

IDEOL: Political complexion of a government, along a 5-point scale, where: $1=$ right-wing dominance (share of seats of government and supporting parties in parliament larger than 66.6 percent); $2=$ right-center complexion (share of seats of right and center parties government and supporting parties between 33.3 and 66.6 percent); $3=$ balanced situation (share of center larger than 5 percent in government and in parliament, or if left and right form a government together not dominated by one side or the other); $4=$ left-center complexion (share of seats of left and center parties government and supporting parties between 33.3 and 66.6 percent); $5=$ left-wing dominance (share of seats of government and supporting parties in parliament larger than 66.6 percent). Source: Woldendorp, Keman, and Budge (2000).

ELFRAC: Index of ethnolinguistic fractionalization, defined as the probability that two randomly selected individuals in a given country will not belong to the same ethnic or linguistic group. Source: Annett (2001). 


\section{References}

Alesina, Alberto, and Tamim Bayoumi, 1996, "The Costs and Benefits of Fiscal Rules Evidence from the U.S. States," NBER Working Paper No. 5614 (Cambridge, Massachusetts: National Bureau of Economic Research).

Alesina, Alberto, and Allen Drazen, 1991, "Why Are Stabilizations Delayed?" American Economic Review, Vol. 81 (December), No. 5, pp. 1170-88.

Alesina, Alberto, Edward Glaeser, and Bruce Sacerdote, 2001, "Why Doesn't the U.S. Have a European-Style Welfare System," NBER Working Paper No. 8524 (Cambridge, Massachusetts: National Bureau of Economic Research).

Alesina, Alberto, Ricardo Hausmann, Rudolf Hommes, and Ernesto Stein, 1999, "Budget Institutions and Fiscal Performance in Latin America," Journal of Development Economics, Vol. 59 (August), pp. 253-73.

Alesina, Alberto, and Roberto Perotti, 1995, "The Political Economy of Budget Deficits," Staff Papers, International Monetary Fund, Vol. 42 (March), pp. 1-31.

1995, "Fiscal Expansions and Adjustments in OECD Countries," Economic Policy, Vol. 21 (October), pp. 205-48.

_ 1997a, "The Welfare State and Competitiveness," American Economic Review: a European Forum, Vol. 87 (December), pp. 921-39.

1997b, "Fiscal Adjustment in OECD Countries: Composition and Macroeconomic Effects," Staff Papers, International Monetary Fund, Vol. 44 (June), pp. 210-48.

Alesina, Alberto, Nouriel Roubini, and Gerald Cohen, 1997, Political Cycles and the Macroeconomy, (Cambridge, Massachusetts: MIT Press).

Alesina, Alberto, and José Tavares,1998, "The Political Economy of Fiscal Adjustments," Brookings Papers on Economic Activity: 1, Brookings Institution, pp. 197-266.

Alesina, Alberto, and Romain Wacziarg, 1998, "Openness, Country Size, and Government," Journal of Public Economics, Vol. 69, pp. 305-21.

Alt, James, David Lassen, and David Skilling, 2000, "Fiscal Transparency and Fiscal Policy Outcomes in OECD Countries" (unpublished; Cambridge, Massachusetts: Harvard University).

Alt, James, and Robert Lowry, 1994, "Divided Government, Fiscal Institutions, and Budget Deficits: Evidence from the States," American Political Science Review, Vol. 88, pp. $811-28$. 
Annett, Anthony, 2001, "Social Fractionalization, Political Instability, and the Size of Government," Staff Papers, International Monetary Fund, Vol. 48, No.3, pp. 561-92.

Austen-Smith, David, 2000, "Redistributing Income Under Proportional Representation," Journal of Political Economy, Vol. 108 (December), pp. 1235-69.

Blanchard, Olivier, and Justin Wolfers, 1999, "The Role of Shocks and Institutions in the Rise of European Unemployment: the Aggregate Evidence," NBER Working Paper No. 7282, pp. 1-34 (Cambridge, Massachusetts: National Bureau of Economic Research)..

Bleaney, Michael, Norman Gemmell, and Richard Kneller, 2000, "Testing the Endogenous Growth Model: Public Expenditure, Taxation, and Growth over the Long-Run," Discussion Paper, No. 00/25, pp. 1-30 (University of Nottingham: Department of Economics).

Bohn, Henning, and Robert Inman, 1996, "Balanced Budget Rules and Public Deficits: Evidence from the U.S. States," NBER Working Paper No. 5533 (Cambridge, Massachusetts: National Bureau of Economic Research).

Bradbury, John Charles, and W. Mark Crain, 2001, "Legislative Organization and Government Spending: Cross-Country Evidence," Journal of Public Economics, Vol. 82 (December), pp. 309-25.

Brumby, Jim, and Marco Cangiano, 2001, "Public Expenditure Management Reform and Fiscal Consolidation in OECD Countries" (unpublished; Washington: Fiscal Affairs Department, International Monetary Fund).

Chari, V.V., and Harold Cole, 1993, "A Contribution to the Theory of Pork-Barrel Spending," Staff Report, No. 156 (July), pp. 1-33 (Federal Reserve Bank of Minneapolis).

Chari, V.V., Larry E. Jones, and Ramon Marimon, 1997, "The Economics of Split-Ticket Voting in Representative Democracies," American Economic Review, Vol. 87, (December) pp. 957-76.

Daveri, Francesco, and Guido Tabellini, 2000, "Unemployment, Growth, and Taxation in Industrial Countries," Economic Policy, Vol. 15 (April), pp. 49-104.

De Haan, Jakob, and Jan-Egbert Sturm, 1994, "Political and Institutional Determinants of Fiscal Policy in the European Community," Public Choice (Netherlands) Vol. 80 (July), pp. 157-72.

_- and Geert Beekhuis, 1999, "The Weak Government Thesis: Some New Evidence," Public Choice, Vol. 101, pp. 163-76. 
Drazen, Allan, 2000, Political Economy in Macroeconomics (Princeton, New Jersey: Princeton University Press).

Edin, Per-Anders, and Henry Ohlsson, 1991, "Political Determinants of Budget Deficits: Coalition Effects Versus Minority Effects," European Economic Review, Vol. 35 (December) pp. 1597-1603.

Fatas, Antonio, and Illian Mihov, 2001, "Fiscal Policy and EMU" (unpublished; Fontainebleau, France: Institut européen d'administration des affaires (INSEAD)).

Grilli, Vittorio, Donato Masciandaro, and Guido Tabellini, 1991, "Political and Monetary Institutions and Public Financial Policies in the Industrial Countries," Economic Policy: a European Forum (U.K.) Vol. 6 (October), pp. 341-92.

Hallerberg, Mark, 2000, "The Importance of Domestic Political Institutions: Why and How Belgium and Italy Qualified for EMU" (unpublished; University of Pittsburgh).

-2001, "EU Institutions and Fiscal Policy Coordination, 1991-2001" (unpublished; University of Pittsburgh).

Hallerberg, Mark, Rolf Strauch, and Jurgen von Hagen, 2001, The Use and Effectiveness of Budgetary Rules and Norms in the EU Member States, Report prepared for the Dutch Ministry of Finance by the Institute of European Integration Studies.

Hallerberg, Mark, and Jurgen von Hagen, 1999, "Electoral Institutions, Cabinet Negotiations, and Budget Deficits in the European Union," in Fiscal Institutions and Fiscal Performance, eds. James Poterba and Jurgen von Hagen (Chicago: University of Chicago Press).

Hemming, Richard, and Michael Kell, 2001, "Promoting Fiscal Responsibility: Transparency, Rules, and Independent Fiscal Authorities" in Fiscal Rules, Research Department, Public Finance Workshop, Banca d'Italia.

International Monetary Fund, 2001, World Economic Outlook, May 2001: A Survey by the Staff of the International Monetary Fund, World Economic and Financial Surveys (Washington).

Kennedy, Suzanne, Janine Robbins, and Francois Delorme, 2000, "The Role of Fiscal Rules in Determining Fiscal Performance," (unpublished; Canada: Department of Finance).

Knight, Brian, and Arik Levinson, 2000, "Fiscal Institutions in the U.S. States," in Institutions, Politics, and Fiscal Policy, eds. Rolf Strauch and Jurgen von Hagen (Boston: Kluwer Academic Publishers). 
Kontopoulos, Yianos, and Roberto Perotti, 1999, "Government Fragmentation and Fiscal Policy Outcomes: Evidence from OECD Countries," in Fiscal Institutions and Fiscal Performance, eds. James Poterba and Jurgen von Hagen (Chicago: University of Chicago Press).

Lijphart, Arend, 1994, Electoral Systems and Party Systems (Oxford, United Kingdom: Oxford University Press).

Lizzeri, Alessandro, and Nicola Persico, 2000a, "The Provision of Public Goods Under Alternative Electoral Incentives," American Economic Review, forthcoming. 2000b, "The Drawbacks of Electoral Competition" (unpublished; Princeton University).

Milesi-Ferretti, Gian Maria, Roberto Perotti, and Massimo Rostagno, 2001, "Electoral Systems and Public Spending," IMF Working Paper 01/22 (Washington: International Monetary Fund).

Nickell, Stephen, and Richard Layard, 1999, "Labor Market Institutions and Economic Performance," in Orley Ashenfelter and David Card [eds.] Handbook of Labor Economics, Vol. 3 (North Holland: Amsterdam).

Persson, Torsten, and Guido Tabellini, 2000a, Political Economics: Explaining Economic Policy (Cambridge: MIT Press).

_ 2000b, "Political Institutions and Economic Policy Outcomes: What Are the Stylized Facts?" (unpublished; Institute for International Economic Studies).

Poterba, James, 1994, "State Responses to Fiscal Crises: 'Natural Experiments' for Studying the Effects of Budgetary Institutions," Journal of Political Economy, Vol. 102, pp. 799-821.

Roubini, Nouriel, and Jeffrey Sachs, 1989, "Political and Economic Determinants of Budget Deficits in the Industrial Democracies," European Economic Review, Vol. 33, pp. 903-38.

Rueben, Kim, 1995, "Tax Limitations and Government Growth: the Effect of State Tax and Expenditure Limits on State and Local Government" (unpublished; MIT).

Scartascini, Carlos, and Mark Crain, 2001, "The Size and Composition of Government Spending in Multi-Party Systems" (unpublished; George Mason University).

Skilling, David, 2001, "The Political Economy of Public Debt Accumulation in OECD Countries Since 1960" (unpublished; New Zealand Treasury).

Spolaore, Enrico, 1993, "Policy Making Systems and Economic Efficiency: Coalition Governments Versus Majority Governments" (unpublished; Harvard University). 
Stein, Ernesto, Ernesto Talvi, and Alejandro Grisanti, 1999, "Institutional Arrangements and Fiscal Performance: the Latin American Experience," in Fiscal Institutions and Fiscal Performance, eds. James Poterba and Jurgen von Hagen (Chicago: University of Chicago Press).

Strauch, Rolf, 2000, "Information and Public Spending: An Empirical Study of Budget Processes in the U.S. States," in Institutions, Politics, and Fiscal Policy, eds. Rolf Strauch and Jurgen von Hagen (Boston: Kluwer Academic Publishers).

Talvi, Ernesto, and Carlos Vegh, 2000, "Tax Base Variability and Procyclical Fiscal Policy," NBER Working Paper No. 7499, pp. 1-36 (Cambridge, Massachusetts: National Bureau of Economic Research).

Velasco, Andres, 1999, "A Model of Endogenous Fiscal Deficits and Delayed Fiscal Reforms," in Fiscal Institutions and Fiscal Performance, eds. James Poterba and Jurgen von Hagen (Chicago: University of Chicago Press).

Von Hagen, Jurgen, 1992, "Budgeting Procedures and Fiscal Performance in the European Communities," Economic Paper No. 96 (Brussels: Commission of the European Communities Directorate General for Economic and Financial Affairs).

Von Hagen, Jurgen, and Ian Harden, 1994, "National Budget Processes and Fiscal Performance," European Economy, Reports and Studies: Towards Greater Fiscal Discipline, No. 3 (Brussels: European Commission, Directorate-General for Economic and Financial Affairs), pp.311-418

1995, "Budget Processes and Commitment to Fiscal Discipline," European Economic Review, Vol. 39, pp. 771-79.

-1996, "Budget Processes and Commitment to Fiscal Discipline," IMF Working Paper 96/78 (Washington: International Monetary Fund).

Von Hagen, Jurgen, Andrew Hughes Hallett, and Rolf Strauch, 2000, Budgetary Consolidation in EMU London: Center for Economic and Policy Research.

Von Hagen, Jurgen, and Rolf Strauch, 1999, "Tumbling Giant: Germany's Experience with the Maastricht Fiscal Criteria" (unpublished; Center for European Integration Studies, University of Bonn).

Weingast, Barry, Kenneth Shepsle, and Christopher Johnsen, 1981, "The Political Economy of Benefits and Costs: a Neoclassical Approach to Distributive Politics," Journal of Political Economy, Vol. 89, pp. 642-64.

Woldendorp, Jaap, Hans Keman, and Ian Budge, 2000, Party Govermment in 48 Democracies (1945-98) (Dordrecht/ Boston/ London: Kluwer Academic Publishers). 